\title{
PROBLEMS OF ENFORCEMENT OF FOREIGN ARBITRAL AWARDS IN THE GULF COOPERATION COUNCIL STATES AND THE PROSPECT OF A UNIFORM GCC ARBITRATION LAW: AN EMPIRICAL STUDY
}

\author{
By
}

Dr. Ahmed M Almutawa* and Professor A F M Maniruzzaman**

*LL.B., LL.M. (Case Western Reserve University, USA), Ph.D. (University of Portsmouth), U.K. He is a
First Lieutenant and legal researcher for the Minister of the Interior, General Directorate of Residency
and Foreign Affairs, Dubai, United Arab Emirates. He is an arbitrator for the International Islamic
Centre for Reconciliation and Arbitration in Dubai and the Ras Al-Khaimah Reconciliation and
Commercial Arbitration Centre.

** LLB (Honours), LLM., M.Int'L.Law (ANU), PhD (Cambridge), MCIArb, FRSA, Professor of International Law and International Business Law, University of Portsmouth, U.K; Honorary Professorial Fellow, CEPMLP, Dundee; Visiting Professor of International Law, China University of Political Science and Law, Beijing and holder of honorary visiting academic positions at Oxford, Cambridge, Western Ontario, Kent and London (QMW) universities. He is a Council Member of the ICC Institute of World Business Law, Paris and Academic Council Member of the Institute of Transnational Arbitration, U.S.A.; member of ILA Committee on International Commercial Arbitration, International Council for Commercial Arbitration and THE IDR GROUP®, London. He is an Advocate of the Supreme Court of Bangladesh and a listed qualified arbitrator of Dubai International Arbitration Centre (DIAC).

\section{INTRODUCTION}

This paper is about a survey conducted to corroborate the conclusions drawn from the literature review in a research on the enforcement of foreign arbitral awards in the Cooperation Council for the Arab States of the Gulf $(\mathrm{CCASG})^{1}$ or as it is often referred to as the "Gulf Cooperation Council" (GCC). ${ }^{2}$ The survey was conducted, among practitioners in the field of arbitration in the GCC states, to determine the perception of practitioners in the field of arbitration regarding arbitration and the enforcement of arbitral awards in the GCC states.

\footnotetext{
${ }^{1}$ See generally, The Cooperation Council for the Arab States of the Gulf, Secretariat General, 'Home' $\square$ http://www.gcc-sg.org/eng/ $\square$ accessed 11 March 2014.

${ }^{2}$ See generally, The Cooperation Council for the Arab States of the Gulf, Secretariat General, 'The Charter' $\square$ http://www.gcc-sg.org/eng/indexfc7a.html?action=Sec-Show\&ID=1 $\square$ accessed 11 March 2014. (Article One states that "A Council shall be established hereby to be named The Cooperation Council for the Arab States of the Gulf, hereinafter referred to as the Cooperation Council (GCC).")
} 
As background, the research examines the need to create a modern unified arbitration law with sufficient enforcement mechanism for the GCC states. The research posits that existing GCC laws and practice of international arbitration, ${ }^{3}$ specifically with regard to the recognition and enforcement ${ }^{4}$ of foreign arbitral awards, are insufficient and must be updated to fully conform to modern international arbitration practice. The research examines and discusses hindrances to the enforcement of arbitral awards under current GCC laws by comparing the arbitration rules under Islamic Shari'a (which is also known and hereafter referred to as the "Shari'a", ), international and regional agreements, and the national arbitration laws of the GCC states. The research concludes that while the Shari'a affects the enforcement of foreign arbitral awards, the substantial number of potential challenges to enforcement in the GCC states stem from the domestic arbitration laws or practice, and not necessarily from the Shari'a. The domestic arbitration laws of the GCC states, therefore, coupled with judges who have limited experience with the Convention on the Recognition and Enforcement of Foreign Arbitral Awards of $1958^{6}$ (New York Convention) and the Model Law of the United Nations Commission on International Trade Law for Arbitration ${ }^{7}$ (UNCITRAL Model Law) are the main culprits for the numerous cases that deny enforcement of foreign arbitral awards. The research concludes with a proposed set of rules relating to the

\footnotetext{
${ }^{3}$ This research generally covers only international commercial arbitration, and non-commercial arbitration such as those dealing with family law is beyond the scope of this research.

${ }^{4}$ For purposes of brevity, any reference to enforcement throughout the rest of this research also refers to recognition and enforcement unless otherwise stated.

${ }^{5}$ The word "Shari' a" in Arabic means "the right path." See Ian Edge (ed), Islamic Law and Legal Theory (Dartmouth 1996) xvi-xvii. See also Essam Alsheikh, 'Court Intervention in Commercial Arbitral Proceedings in Saudi Arabia: A Comparative Analytical Study of Shari'a Based Statutes and International Arbitral Practises' (PhD thesis, University of Portsmouth 2011) Ch 2, fn 2; Abd Ar-Rahman and Abdassamad Clarke, Shari'a Islamic Law (Ta-Ha Publishers 2008) 23 (stating that "the literal meaning of the word Shari'a in Arabic is 'the way to a watering place'. More generally, it is taken to mean 'the road to be followed'. Allah, the Creator, has revealed this path to the mankind through the Prophet, His Messenger.") Islamic law is also known as the Shari'a. It is, however, difficult to accept the references to the Shari' a "Shari' a law" since Shari'a in the Arabic sense also encompasses the meaning of the words "law" and "rule." To say "Shari' law" is in essence a misnomer and the same as saying "Law law." For Islam, there is no distinction between Shari' a and any other law because the definition of Shari'a in Arabic is "law and rule" given by God, but a distinction later arose through use of the word Shari'a in the English language and some erroneously use the phrase "Shari'a law." The more appropriate term is Islamic Shari'a or to simply refer to it as the Shari'a.

${ }^{6}$ Convention on the Recognition and Enforcement of Foreign Arbitral Awards, 10 June 1958, art V(2)(b), 21 UST 2517, 330 UNTS 38 [hereinafter New York Convention]; see International Legal Framework, (1994) 1 World Arb Rep 1, 37 (listing accession dates for all New York Convention signatories).

${ }^{7}$ The UNCITRAL Model Law on International Commercial Arbitration 1985 with amendments as adopted in 2006.
} 
enforcement of foreign arbitral awards, which balances the requirements of the Shari'a with the norms of international arbitration, to be included in a prospective Uniform GCC Arbitration Law.

The survey, therefore, intends to corroborate the conclusions drawn from the literature review by measuring the perception of those with experience in the field of arbitration in the GCC states regarding the definition of domestic, foreign or international award in their respective jurisdictions. The survey also attempts to measure the perception of the same group on whether courts in the GCC states apply the same or different conditions of enforcement to domestic and foreign arbitral awards. Further, the survey weighs the perception of the same group on what are the most likely reasons for the non-enforcement of foreign arbitral awards in the GCC states, including the perception of the group on the extent to which judges in the GCC states are familiar with the New York Convention, the UNCITRAL Model Law, and the ICSID Convention. The survey also appraises the views of the same group as to the role of the Shari'a in determining the public policy defence. Finally, the survey evaluates the sounding of the same groups regarding a prospective Uniform GCC Arbitration Law, and their views on potential language to be proposed for inclusion in that Uniform Law. The general purpose of the survey was to complement the findings in the literature review, including the divergent views of Western practitioners and Arab practitioners with regard to the role and impact of the Shari'a on the enforcement of arbitral awards.

Section 2 discusses the research methodology adopted in the paper, including the observations from the literature, a description of the participants to the survey, the survey design, the design of the survey questions, pilot testing of the survey, distribution of the survey via online, and the data analysis. Section 3 discusses the survey results. This section covers a discussion as to the background of the participants, rating questions, open-ended questions, whether participants were in favour of a Uniform GCC Arbitration Law, questions relating to the conditions for enforcement of arbitral awards, the effect of the Shari'a on the enforcement of arbitral awards, and questions that test the proposed set of rules for a prospective Uniform GCC Arbitration Law. Section 4 appraises the lessons learnt from the empirical perspective. Finally, section 5 makes some concluding remarks. 
It is hoped that this study will inform the governments of the GCC states, their policy makers and legislators, arbitrators and practitioners of the prospect of a Uniform Arbitration Law and advise them that it is the high time to realize it.

\section{RESEARCH METHODOLOGY}

\subsection{Introduction}

The research methodology adopted in this empirical study comprises both qualitative and quantitative approaches. The qualitative approach is primarily made through an extensive review of the literature on the subject concerned and then the findings therefrom were tested by a survey (by a questionnaire) on the representative samples of population in the field concerned for the quantitative purpose.

The primary data gathered from the survey will be used to test some of the findings of the research, more specifically the following specific points:

1. the friendliness of the GCC states towards the enforcement of foreign arbitral awards;

2. reasons for the non-enforcement of a foreign arbitral award in specific jurisdictions;

3. the extent to which the GCC states judges are familiar with the New York Convention, the UNCITRAL Model Law, and the ICSID Convention;

4. to determine the opinion of those in the arbitration field in the GCC states concerning:

i. the codification of a prospective Uniform GCC Arbitration Law;

ii. the suitability of the UNCITRAL Model Law;

iii. the status of the Shari'a in international arbitration; 
iv. the applicability of the Shari'a in determining a GCC state's

public policy as it pertains to the enforcement of foreign arbitral awards;

v. the definition for domestic, foreign, and international arbitral awards;

vi. the question whether domestic and foreign arbitral awards should have the same or different conditions for enforcement; and

vii. some specific rules proposed by this study for incorporating into a prospective Uniform GCC Arbitration Law.

Before conducting the survey, a pilot study was made, after which the survey was disseminated to potential participants online through Survey Monkey (www.surveymonkey.com). Below are further explanations of the survey methodology, the procedures, and the analysis of the survey data.

\subsection{Observation from the Literature}

It is necessary to discuss first the observations that were made from the literature review before further discussing the survey, since the survey will be used to corroborate the conclusions drawn from such literature review.

The literature review in the research reveals that after comparing the Shari'a, international agreements and GCC domestic laws, four main reasons emerge as the major challenges to the enforcement of arbitral awards in the GCC states: (1) unclear and inconsistent definitions of a domestic, foreign, or international arbitral award, ${ }^{8}$ (2) additional conditions for the enforcement of an arbitral award required by the GCC

\footnotetext{
${ }^{8}$ Michael Hwang and Shaun Lee, 'Survey of South East Asian Nations on the Application of the New York Convention' (2008) 25(6) J of Intl Arb 873-892, stating that "the lack of universality as to which awards the New York Convention applies to is derived from the differing definitions of what constitutes a domestic award, as well as the reservations made to the NYC. As a result, there is no 'one-size-fits-all' approach."
} 
states through their domestic legislation, (3) judicial activism ${ }^{9}$ in allowing additional grounds for challenging the enforcement of arbitral awards, ${ }^{10}$ and (4) an overly broad interpretation of public policy. ${ }^{11}$ The literature review also reveals that judges often cloak their activism behind the mantle of the Shari'a when, in fact, the Shari'a is largely consistent with the New York Convention. ${ }^{12}$

One of the underlying premises behind the research is that a set of rules on enforcement in a prospective Uniform GCC Arbitration Law is necessary and can be accomplished through a harmonisation ${ }^{13}$ of the Shari'a with the New York Convention and the ICSID Convention. Shari'a trained judges, or judges with a strong Shari'a background, in the courts of the GCC states, in determining whether an arbitral award is foreign or domestic, will likely be influenced by the Shari'a. ${ }^{14}$ It is, therefore, important to examine the Shari'a concept of "foreign." In addressing the definition of "foreign"

\footnotetext{
${ }^{9}$ Hamid Gharavi and Lara Karam, 'Arbitration in Yemen' (2006) 17 ICC International Court of Arbitration Bulletin 41, 44.

${ }^{10}$ AFM Maniruzzaman, 'International Commercial Arbitration in the Asia Pacific: Asian Values, Culture and Context' (2002) 30 Int'l Bus Lawyer 11, 508, 512 (outlining the obstacles to arbitration in Asian countries and referring to judicial interference on the basis of public policy); Hubco $v$ WAPDA, Civil Appeal Nos 1398 and 1399 of 1999 (Pakistan), (2000) 16 Arbitration Int'l 439.

${ }^{11}$ Public policy is a common provision found in the New York Convention and national legislation. Ariel Ezrahi, 'Arbitration in the Arab Middle East, a Snapshot' (2005) 20-11 Measley's Int'l Arb Rep 17, 5; Albert van den Berg, The New York Arbitration Convention of 1958: Towards a Uniform Judicial Interpretation (Kluwer 1981), op cit 360 (stating that "the reason why the concept of public policy is so difficult to grasp is that the degree of fundamentality of moral conviction or policy is conceived differently for every case in the various states"); Hussam Al-Talhuni, 'The Effect of Public Policy on the Enforcement of Foreign Arbitral Awards' (PhD thesis, The University of Edinburgh 2002) 69.

${ }^{12}$ Faisal Kutty, 'The Shari' a Factor in International Commercial Arbitration' (2006) 28 Loy LA Int'l \& Comp L 1, 1-3, (2009) 4 J of Arab Arb 63.

${ }^{13}$ See generally, Mary Ayad, 'International Commercial Arbitration and Harmonisation of Contract Law with a Focus on Reform in the Mena Region’ (2009) 6 MqJBL 93, 96; William Ballantyne, Arab Comparative and Commercial Law: The International Approach (Graham Trottman 1987) vol 1. ${ }^{14}$ Kutty (n 12) 1-3.

15 Abdullah Alassaf and Bruno Zeller, 'The Legal Procedures of Saudi Arbitration Regulations 1983 and 1985' (2010) 7 MqJBL 170, 186; Gitanjali Bajaj, 'Arbitration in the Kingdom of Saudi Arabia' (DLA Piper News 2009) $\square$ http://www.dlapiper.com/arbitration-in-the-kingdom-ofsaudi-arabia/ $\square$ accessed 18 January 2014 (explaining that "the mentioned secondary sources of Shari' ah rules are used to form the fiqh (jurisprudence)... as an analysis and clarification source of Shari' ah is completely based on the understanding and awareness of the religious scholars and judges."); Abdulrahman Baamir and Ilias Bantekas, 'Saudi Law as Lex Arbitri: Evaluation of Saudi Arbitration Law and Judicial Practice' (2009) $25 \mathrm{~J}$ of Arb Int'l 239. Saleh has proposed that the definition of a "foreign" arbitral award under the Shari' a as "an award made under a law other than the Shari'a." Samir Saleh, Commercial Arbitration in the Arab Middle East (2nd edn, Hart Publishing 2006) 64-65. But see, AA Commercial Co v S Motors Ltd Co and D Industrial Ltd Co, Abu-Dhabi Court of Appeal, Case No 10007/1981 unpublished, stating that it is a widespread error in the UAE to presume that applying a foreign law or international treaty is violating the Shari' a just because it is foreign. See also, G Steel Industry Co v International Steel and Contractors Co, UAE Supreme Court Case No 138/10, unpublished.
} 
arbitral award under the Shari'a, ${ }^{16}$ one is able to clarify the Shari' a distinction between domestic and foreign, ${ }^{17}$ as expressed by different scholars, whether from the Maliki, Hanbali, and Shafi'i or Hanafi schools. ${ }^{18}$ Overall, a review of the literature reveals that the New York Convention's definition of foreign and non-domestic arbitral awards is compatible with the Shari'a. ${ }^{19}$

Additionally, a review of the literature reveals that the conditions for the enforcement of arbitral awards under the Shari' ${ }^{20}$ (though potentially expansive in some areas like public policy when applied by an enforcing court) is not burdensome. ${ }^{21}$ There are, in fact, fewer conditions placed by the Shari'a than by the domestic laws of the GCC states. 22

In other words, domestic courts and national legislation are for probable obstacles to the enforcement of foreign arbitral awards as they may require additional conditions that are protectionist in nature, or that are motivated by distrust of other countries' legal systems and procedures. ${ }^{23}$ The source of this distrust, within the context of the GCC states is often misplaced on the Shari'a, but a careful analysis of the specific conditions that each GCC state places on foreign arbitral award enforcement is too often unrelated to the Shari'a.

\footnotetext{
${ }^{16}$ Abdul Hamid El-Ahdab and Jalal El-Ahdab, Arbitration with the Arab Countries (3rd edn, Wolters Kluwer 2011) 50.

${ }^{17}$ Omar El-Kadi, L'Arbitage International entre le Droit Musulman et le Droit Francais et Egyptien (PhD thesis, University of Paris 1984) 327. See Saleh (n 15) 57-65 (stating that "In Shari'a, the foreign character of a party to an agreement is based not on the concept of nationality but on religion.").

${ }^{18}$ Syed Khaled Rashid, 'Alternative Dispute Resolution in the Context of Islamic Law' (2004) 8 Vindobona J Intl Com L 95; El-Ahdab, Arbitration with the Arab Countries (n 16) 50; Abu Hanifa, Badaei El Sanaei, 132, et seq; Abu Yussef, Badaei El Sanaei, 132, et seq; Imam Malik, Mawaheb Al Jalil, vol III, 355; Imam Shafi'i, AL Muhazab, vol II, 358; Imam Ibn Hanbal, Al Mughni, vol X 439; Al Charh Al Kabir, vol IV 383.

${ }^{19}$ Albert Jan van den Berg, 'When is an Arbitral Award Nondomestic Under the New York Convention of 1958?' (1985) 6 Pace L Rev 25, , referring to Law of Mar 15, 1961, § 2, Bundesgesetzblatt [BGBI] II, 121 (W Ger) (van den Berg used as an example the West German law which applies the New York Convention to an award made abroad even if it would have been deemed domestic for having employed German procedural law).

${ }^{20}$ Alsheikh (n 5); Kutty (n 12) 63; Abdulrahman Baamir, Shari'a Law in Commercial and Banking Arbitration: Law and Practice in Saudi Arabia (Ashgate 2010); El-Ahdab, Arbitration with the Arab Countries (n 16).

${ }^{21}$ Gabriel Moens and Roger Jones (eds), International Trade and Business Law Review, vol XII (1st edn, Routledge-Cavendish 2009) 156; Charles Brower and Jeremy Sharpe, 'International Arbitration and the Islamic World: The Third Phase' (2003) 97 AJIL 643.

${ }^{22}$ Baamir (n 20).

${ }^{23}$ See generally El-Ahdab, Arbitration with the Arab Countries (n 16); Essam Al-Tamimi, Practitioner's guide to arbitration in the Middle East and North Africa (JurisNet LLC 2009).
} 
A review of the literature shows that after analysing the conditions placed by each of the GCC states prior to the enforcement of a foreign arbitral award, it is possible to conclude that the conditions placed by each of the GCC states are much more restrictive and more of an impediment to enforcement than the Shari'a itself and the New York Convention. ${ }^{24}$ In this regard, the additional conditions placed by the GCC states are likely the reason for the non-enforcement of foreign arbitral awards. When domestic courts have looked at the New York Convention as a guide to enforcement (instead of focusing solely on the domestic legislation) there seems to be more success in enforcement. On the other hand, the failure of domestic courts to adhere to the proenforcement bias of the New York Convention and their taking a protectionist stance in favour of domestic concerns lead to the non-enforcement of foreign arbitral awards. Courts could perhaps take note of the position of the Cairo Court of Appeals in the Seventh Commercial Circuit, Case No. 50/128j (4 January 2012), ${ }^{25}$ which explained that failure to meet certain conditions ought not to automatically lead to nonenforcement or annulment, especially taking into account the possibility that one of the parties may have proceeded with the arbitration and waived such defects in the conditions. A more liberal and flexible stance by the GCC states' judges with regard to the conditions, which looks toward the bias in favour of enforcement, would be a positive step forward for international arbitration in the region.

The research proposes that the GCC states can find commonality in their laws relating to the enforcement of foreign arbitral awards. By doing so, the GCC states may be able to arrive at a set of conditions that are more in line with the New York Convention, but still take into account the Shari' ${ }^{26}$ and the conditions for enforcement common to the GCC states. They can perhaps agree on a Uniform GCC Arbitration Law for determining the proper conditions to be met in order to enforce a foreign arbitral award. ${ }^{27}$

\footnotetext{
${ }^{24}$ ibid.

${ }^{25}$ Cairo Court of Appeals, Seventh Commercial Circuit, Case No 50/128j (4 January 2012).

${ }^{26}$ Ayad (n 13) 96; Ballantyne (n 13) vol 1.

${ }^{27}$ Moussa Alezri, 'The Role of the Omani Judiciary in Supporting Arbitration' (2010) 2 J of Arab Arb 26, stating that "unifying the rules that organize arbitration on the GCC level is important, as is the adoption of the UNCITRAL Model Law by all states." (Judge Alzeri makes numerous other recommendations with regard to improving arbitration in the GCC, including reviewing laws and regulations that impede the development of international commercial arbitration.); Amr Elattar, Enforcement of International
} 
The New York Convention is a common thread and a point of convergence (for the enforcement of foreign arbitral awards) for the Shari'a, regional conventions, and the national laws of GCC states. The ICSID Convention, of course, is a different creature altogether, allowing only a challenge during execution of the ICSID arbitral award, but not during enforcement. ${ }^{28}$ The divergence occurs primarily when the national laws of the GCC states allow additional grounds for challenging a foreign arbitral award.

On paper, since all the GCC states ratified the New York Convention, the potential challenges to the enforcement of a foreign arbitral award are consistent with international arbitration norms. In practice, however, the other GCC states like the UAE continue to deviate from the international practice, allowing for additional grounds for challenging the enforcement of foreign arbitral awards than permitted under the New York Convention. ${ }^{29}$ The Riyadh Convention likewise incorporates the Shari'a as a ground for challenging the enforcement of foreign arbitral awards. ${ }^{30}$ In reality, however, the grounds for challenging the enforcement of foreign arbitral awards under the Shari'a

\footnotetext{
Arbitration Awards: A Comparative Study between Egypt, USA, and the Gulf Cooperation Council Countries (LAP Lambert Academic Publishing 2013) 398-399 (proposing that Kuwait and Qatar should adopt the UNCITRAL Model Law and should revise their rules on the finality of awards under each country's Civil Procedures law). See also, Ahmed Sheta, 'GCC Unified Arbitration Draft Law' (2009)1 J Arab Arb 92, 93; El-Ahdab, Arbitration with the Arab Countries (n 16) 573; Meriam Alrashid and others, 'International Arbitration in the Middle East: A Case Study of Qatar' The International Dispute Resolution News (Fall 2009) vol 1, No 1, 13; Nadim Kawach, 'Gulf states plan single arbitration law' (Emirates Business 24/7, 22 August 2009) $\square$ http://www.emirates247.com/eb247/economy/uaeeconomy/gulf-states-plan-single-arbitration-law-2009-08-22-1.30548 $\square$ accessed 20 February 2014; Ahmed Sheta, the Secretary General of the Qatar Center for Arbitration and Conciliation (QICA), commented in April 2009 that the law would be adopted within a year. Satish Kandady, 'Unified GCC Arbitration Law Set to Take Effect Next Year' The Peninsula (Doha, 7 April 2009)

$\square$ http://www.thepeninsulaqatar.com/Display_news.asp?section=business_news\&month=april2009\&file= business_news2009040722050.xml $\square$ accessed 21 February 2014; 'Draft of Unified Law for Arbitration in States of Gulf Cooperation Council' (2009) 1 J Arab Arb 559, 573 (“QICA Draft Unified Law”).

${ }^{28}$ Lucy Reed, Jan Paulsson and Nigel Blackaby, Guide to ICSID Arbitration (Wolters Kluwer 2010) 182184. See also Ivar Alvik, Contracting with Sovereignty: State Contracts and International Arbitration (Hart Publishing, 2011), pp. 119-20.

${ }^{29}$ See Ahmed Almutawa and AFM Maniruzzaman, 'The UAE's Pilgrimage to International Arbitration Stardom - A Critical Appraisal of Dubai as a Centre of Dispute Resolution Aspiring to be a Middle East Business Hub' (2014) J World Inv Trade 15, 193-244; Al Tamimi (n 23) 46. See also Mark Hoyle, 'Topic in focus: demystifying UAE arbitration law' (Lexology, 8 November 2013) $\square$ http://www.lexology.com/library/detail.aspx?g=fc4ff6d6-cafb-4063-8dc1-f20fc1544c9e $\square$ accessed 15 January 2014 (stating that many procedural matters in the UAE become a public order or public policy issue); Dubai Court of Cassation Judgment 267/99 (November 1999); Dubai Court of Cassation Judgment 17/2001 (3 October 2001).

${ }^{30}$ Ezrahi (n 11) 5-6.
} 
do not become a significant factor for whether a foreign arbitral award will be enforceable.

Instead, a review of the literature reveals that the majority of successful challenges to foreign arbitral awards are based on the national legislation of each GCC state and the practice employed by courts inexperienced with the New York Convention. ${ }^{31}$ The GCC states could improve their mechanisms for enforcing foreign arbitral awards if they create a Uniform GCC Arbitration Law that is consistent with their existing obligations under the New York Convention while keeping in mind the Shari'a.

Any sort of proposals to improve the enforcement of foreign arbitral awards in the GCC states, however, has to take into account public policy. ${ }^{32}$ While it seems, at first glance, that the public policy of the GCC states ought to be the same because all GCC states adhere to Shari'a public policy, ${ }^{33}$ a closer review of the literature reveals a landscape that is just as fraught with nuances over the concept of public policy as any

\footnotetext{
${ }^{31}$ AA Commercial Co v S Motors Ltd Co and D Industrial Ltd Co, Abu-Dhabi Court of Appeal, Case No 10007/1981 unpublished; Abu Dhabi Court of Cassation, Petition No 814/2011, Judgment of 21 December 2011; Bahrain Supreme Court, Challenge No 241 of 2008 (17 November 2008); Baiti Real Estate Development v Dynasty Zarooni Inc, Dubai Court of Cassation, Appeal No 14/2012, Real Estate Cassation (16 September 2012); Case No 127, Appeal No 10/2000, Supreme Court Decision (Oman); Dubai Court of Appeal, Civil Petition No 531/2011, Judgment of 6 October 2011; Dubai Court of Cassation, Petition No 17/2001, Judgment of 10 March 2011; Federal Supreme Court, Petition No 32, 23rd Judicial Year, Judgment of 8 June 2003; Final Award No 7063 (1993), (1997) 22 YB Comm Arb 87, IADR Ref No 112 (Saudi Arabia); Fujairah Federal Court of First Instance, Commercial Case No 35/2010, Judgment of 27 April 2010; G Steel Industry Co v International Steel and Contractors Co, UAE Supreme Court Case No 138/10, unpublished; High Federal Court of Abu Dhabi, Annulment Case No 891, Commercial Cassation, Hearing held 17 June 2006; Kuwait Court of Appeals, Request for Arbitration No 16/2001 (8 May 2006); Oman Appeal Circuit, Hearing session held on October 19, 1998, Case No 2/98 Arbitration, (2010) J of Arab Arb 198; Qatari Court of Appeals, Case No 107/1994, Judgment rendered in the hearing of 8 May 1995, (2009) J Arab Arb 438; Saudi Arabia Court of Grievance, Commercial Circuit, Case No 1767/2/J of 1422 AH, Ruling No 183/C/C/9 of 1425 AH. ${ }^{32}$ The concept has been subject to debate among courts, and remains controversial. Arthur Nussbaum, 'Public Policy and the Political Crisis in the Conflict of Laws' (1940) 49 Yale L J 1027; Al-Talhuni (n 11) 62; Wasim Al-Jerafi, 'Yemen's Ratification of the New York Convention: An Analysis of Compatibility and the Uniform Interpretation of Article $\mathrm{V}(1)(\mathrm{A})$ and $\mathrm{V}(2)(\mathrm{B})$ ' (PhD thesis, University of Leicester 2013) 155; Gary Born, International Commercial Arbitration, vol I (Kluwer 2009) 247.

${ }^{33}$ See Abdul Hamid El-Ahdab, 'General Introduction on Arbitration in Arab Countries' in Pieter Sanders (ed), International Handbook on Commercial Arbitration (Kluwer 1993) 12 (defining public policy as "based on the respect of the general spirit of the Shari'a and its sources (the The Holy Qur'an and the Sunna, etc) and on the principle that individuals must respect their clauses, unless they forbid what is authorized and authorize what is forbidden"); Samir Saleh, 'The Recognition and Enforcement of Foreign Arbitral Awards in the States of the Arab Middle East' (1985) 1 Arab L Q 19, 26 (one of the earliest discussion of Islamic public policy); Abd Al-Razzaq Al-Sanhouri, Study on the new civil law [Al Wassit fi Sharh Al Qanun Al Madani Al Jadid] (Ahmad Al-Maraghi ed, 2007) vol 1, 300 et seq.
} 
part of the world. ${ }^{34}$ While there are large patches of commonality, each GCC state does differ at one point or another as to what constitutes public policy. ${ }^{35}$

A common thread appears as to the division between procedural and substantive public policy under the Shari'a, international agreements, and the jurisprudence of each of the GCC states. There seems to be more in common amongst the Shari'a, international agreements, and even each of the GCC states with regard to procedural public policy, which is largely concerned with fairness and due process. ${ }^{36}$ It is with substantive public policy that a substantial divergence in the concept of public policy begins to emerge. This is true with regard to both express substantive public policy and implied substantive public policy, or arbitrability.

While there are differences in the concept and scope of public policy amongst the Shari'a, international agreements, and the jurisprudence of each of the GCC states, the differences that stem from the Shari'a could be narrowed to a very limited set of cases that when viewed in totality constitute a minute portion of arbitration cases. ${ }^{37} \mathrm{In}$ this sense, what becomes the source for the obstacles to enforcement under the umbrella of public policy is whether a GCC state's judiciary applies public policy narrowly or broadly. In the context of the GCC states, there is a tendency for judges, whenever the Shari'a is invoked, to cast a wide net in favour of public policy. There are, however, signs that such an approach is not necessarily the only path under the Shari'a, as is currently being demonstrated by recent cases coming from the UAE courts. ${ }^{38}$ It is ultimately possible for all GCC states to balance the Shari'a and international arbitration

\footnotetext{
${ }^{34}$ Husain Al Baharna, 'The Enforcement of Foreign Judgments and Arbitral Awards in the GCC Countries with Particular Reference to Bahrain' (1989) 4 Arab LQ 332, 332-344 (stating that "the diversity of the laws and procedures in the GCC countries, coupled with the fact that some of them have not yet passed legislation on the topic, make the task of this study not so easy.")

${ }^{35}$ Saleh (n 33) 26 ("It is noteworthy that most of the courts in the [GCC states] have not yet defined public policy.").

${ }^{36}$ Al-Jerafi (n 32).

37 ibid.

${ }^{38}$ See Almutawa and Maniruzzaman (n 29). See also Fujairah Federal Court of First Instance, Case No 35 of 2010, Judgment of 27 April 2010 (enforcing a foreign arbitral award under the New York Convention); Abu Dhabi Court of Cassation, Appeal No 519 of 2013, Decision on 2 October 2013 (in a pro-arbitration and pro-enforcement decision, the court held that an award-creditor can seek a precautionary attachment order without needing to first ratify the award); Robert Karrar-Lewsley, 'UAE: attachment orders apply while recognition is pending' (Lexology, 23 January 2014)

$\square$ http://www.lexology.com/library/detail.aspx?g=42bd95b7-730a-4341-b93a-d2d064e911fd $\square$ accessed 24 February 2014.
} 
concepts of public policy. ${ }^{39}$ As Wakim suggests, however, to arrive at this balance, "all this requires government function and public policy value judgments to be open and accessible. ${ }^{, 40}$

A review of the literature suggests that setting aside of foreign arbitral awards remains an unsettled area of international arbitration, that continues to create conflicting, and certainly non-uniform rules or application of rules, not only for the GCC states but also for countries like France and the USA. ${ }^{41}$ In the midst of this muddled jurisprudence, ${ }^{42}$ the GCC states strive to strike a balance of embracing the international arbitration norms and standards, while trying to remain consistent with the Shari'a and protect national interests.

The Shari'a itself only provides a general rule for the setting aside of an arbitral award. ${ }^{43}$ What remains are the New York Convention and the UNCITRAL Model Law, one the one hand, and the national arbitration laws of each of the GCC states on the other. It seems that since the GCC states are all signatories to the New York Convention, and lacking any substantial difference between the New York Convention and the Shari'a on setting aside, the GCC states ought to uniformly replace the grounds for setting aside under its national laws with the grounds under the UNCITRAL Model Law, ${ }^{44}$ which follows the New York Convention. Such an approach would be simple and achievable for the GCC states to arrive at a uniform system for enforcing foreign arbitral awards.

The above observations from the literature gives a background to the survey conducted and whether the survey achieves its goal of corroborating the conclusions drawn therefrom.

\footnotetext{
${ }^{39}$ Elana Levi-Tawil, 'East Meets West: Introducing Shari'a Into the Rules Governing International Arbitrations at the BCDR-AAA' (2011)12 Cardozo J of Conflict Resolution 609.

${ }^{40}$ Mark Wakim, 'Public Policy Concerns Regarding Enforcement of Foreign International Arbitral Awards in the Middle East' (2008) 21 NY Int'l L Rev 1, 50.

${ }^{41}$ Robert Bird, 'Enforcement of Annulled Arbitration Awards: A Company Perspective and an Evaluation of a “New” New York Convention' (2011-2012) 37 NCJ Int'l L \& Com Reg 1013.

${ }^{42}$ Mohamed Al-Siyabi, 'A Legal Analysis of the Development of Arbitration in Oman with Special Reference to the Enforcement of International Arbitral Awards' (PhD thesis, University of Hull 2008) 77.

${ }^{43}$ Alsheikh (n 5) 52; El-Ahdab, Arbitration with the Arab Countries (n 16) 51. See also Radwa Elsaman, 'Factors to Consider Before Arbitrating in the Arab Middle East: Religious and Legislative Constraints' (2011) 3 Geo Mason J Int'l Com L 1, 62-63; El-Kadi (n 17).

${ }^{44}$ UNCITRAL Model Law, art 34(2).
} 


\subsection{Participants}

The participants in the survey, only one survey population, consisted of individuals who engage or practise law in the field of international arbitration in the GCC states. The estimated potential size of the population ranged from 30 to 300 . The estimated number of potential participants was based on the number of individuals who engage or practise law in the field of international arbitration in the GCC states, and whose contact information (primarily email) is publicly available on the Internet. In the end, the survey was sent to a total of 321 potential participants. Of this number only 41 participated in the survey (11 more than the 30 respondents as was originally anticipated).

The sample size does not consist of the entire relevant population, as there are practitioners who practise international arbitration in the GCC states whose contact information is not publicly available. However, the survey was also disseminated to some groups including the International Islamic Centre for Reconciliation and Arbitration, the GCC Arbitration Centre, and the DIAC, which were requested to send the survey to their mailing list. It is recognized, however, that many of the potential participants are attorneys and arbitrators with very busy schedules and may not have the time to participate in the study.

The survey assumed that five (5) individuals from each of the six GCC states would, at a minimum, respond to the survey, giving the sample survey population a minimum of 30 to 40 participants. If more than five (5) individuals from each of the six GCC states responded to the survey, then it was expected to obtain more than 30 participants. An email of the survey via Survey Monkey was sent to individuals who engage or practise law in the field of international arbitration in the GCC states, and whose contact information is publicly available on the Internet.

\subsection{Survey Design}

The Survey Questions consisted of 31 questions for a ten-minute survey. The questions were divided into four parts. Part I asked for General Background 
Information. Part II asked participants to give a scaled rating with a range of zero "0" to ten "10". Part III asked participants to provide a short answer, to choose from multiple choices and provide a short answer, and to choose from multiple choices. Finally, part IV asked participants to read a statement and to state whether they agreed or disagreed with the statement. Those who disagreed were asked to state their reasons in paragraph format why they disagreed with the statement.

\subsection{Question Design}

There are generally four types of survey questions: (1) open ended; (2) multiple choice; (3) ranking; and (4) scaled. An open-ended question allows the participant or respondent to state a full range of answers in his or her own words, allowing for further or in-depth insight into the perceptions of the participant. An open-ended question, however, requires careful analysis of text, requires more time to complete for a participant, and complicates data summary and analysis. Its advantages, however, are to provide detail and depth, to clarify the participants' ideas, and to generate new ideas about a topic.

A multiple choice question simply asks the participant to choose from one or more answers, and is therefore useful in gathering demographic data and/or data on a range of issues. Multiple-choice questions allow for asking many questions in a short amount of time and can assess attitudes when the issues are clear. Multiple choice questions can be either close-ended or partial open-ended. A close-ended multiple choice question is fast and easy to complete for the participant and enables easy data entry and data analysis. However, the responses lack detail and depth and are limited to the options provided. The partial open-ended multiple-choice question allows for the participant to choose an "Other" choice when the participant is not satisfied with the choices provided. So, the partial open-ended takes the advantages of a close-ended multiple-choice question while allowing the participant to provide more in-depth or detailed answers. The disadvantage of a partial open-ended question is that it complicates data analysis. 
A ranking question asks the participant to put in order or rank a series of choices or to choose from a set of ordered choices. In other words, it asks the participant to determine the relative importance of various choices. A ranking question, however, can be difficult to answer and limits the response choices for the participant.

A scaled question determines the degree of a response, opinion or position by asking the participant to choose from an interval or scale of numbers. The scaled question can allow for a more precise determination of a degree rather than by asking a simple yes or no, while still remaining easy to complete for the participant and for easy data entry and data analysis for the researchers.

In this survey, the open-ended question, close-ended multiple choice question, partial open-ended multiple choice question, and the scaled question were employed. Close-ended multiple choice questions were employed for both demographic questions and for specific questions. An example of a multiple-choice question is the following: "Do you practise in the field of arbitration?" The answer had two choices: "Yes" or "No".

The partial open-ended multiple-choice question was also used whenever the potential answer could result in unforeseen choices that would be important for the participant. An example of a partial open-ended multiple-choice question is the following: "What is your profession?" The participants had the following answer options: “Attorney," “Arbitrator," "Judge," "Legal Consultant," or "Other (please specify)".

The open ended question was also used to solicit additional and in-depth insight that could determine whether the conclusion drawn from the literature review generally matched that of the sample population. An example of an open-ended question is the following question: "What is the most likely reason for the non-enforcement of a foreign arbitral award in your jurisdiction?" The participants were then given a blank field to fill-in an answer without any length limit or requirement.

Finally, the scaled question was employed to rate the degree to which participants viewed friendliness to arbitration, extent of knowledge, degree of benefit, and degree of satisfaction. A 10-point scale was used so that the data could easily be converted to a percentage. For example, an answer of 5 is equivalent to $50 \%$. Also, a 
study has shown that a scale with 5-7 point scales tend to produce higher mean averages than a scale with a 9 or 10 point scale. ${ }^{45}$ An example of this question is as follows: "In a scale of $0-10$, where 0 is "least friendly," how would you rate the friendliness of the following countries towards the enforcement of foreign arbitral awards?" The participants were then asked to rate the following countries: Kingdom of Bahrain, State of Kuwait, Sultanate of Oman, State of Qatar, Kingdom of Saudi Arabia, and United Arab Emirates.

Another question type used is a mixed version of the multiple-choice question with an open-ended question that follows. The question asked the participant to read a statement and asked whether they agreed or disagreed with the statement. The closeended multiple-choice question is easy to answer and easy for data entry and data analysis. Meanwhile, whenever the answer is "Disagree", the participant is then asked an open-ended question requesting for their reasons for disagreeing. The purpose of the follow-up open-ended question is to solicit new ideas and to gain in-depth insight into the participant's objection to the statement. An example of this type of question is the following question, which asked the participants to consider the following statement(s): "A foreign arbitral award is an arbitral award that was made in the territory of a State, such state being a signatory to the New York Convention if required by a GCC state, other than the State where the recognition and enforcement of such arbitral award is sought, and arising out of differences between persons, whether physical or legal. The New York Convention shall apply to the enforcement of all foreign arbitral awards, including the interpretation of this provision." The participants were then asked the following question: "Do you agree or disagree with the entire statement?" The answer options to the question were either "Agree" or "Disagree". If a participant disagrees, the participant is prompted to answer the following question: "If you disagree, please state why." The participant is then given a blank field to answer the open-ended question without requirement or limit.

In this survey, short and simple questions where attempted whenever possible, and leading questions were avoided. Most of the questions were close-ended, but

\footnotetext{
45 John Dawes, 'Do Data Characteristics Change According to the Number of Scale Points Used?: An experiment using 5-point, 7-point and 10-point scales' (2008) Int'l J of Market Research 50, 61-77.
} 
partial-open ended and open-ended questions were opted for whenever it was necessary to solicit a more in-depth or detailed answer from the participant. To make it easier for the participant to complete the survey fewer or limited answer choices were offered. The scaled questions invite more information to provide comprehensiveness as partially complete surveys may end right before the scaled questions. The scaled questions were thus necessary as the completed survey yielded very valuable data. Finally, the research aimed to make the survey easy to take, and so the research made sure to provide a logical order to the survey and made the survey neat and orderly.

\subsection{Pilot Testing}

The survey was pilot tested before dissemination to uncover errors in the survey design and to fine tune the questions and uncover potential flaws and potential causes of confusion, such as misleading questions. The pilot survey was sent to a few initial participants who made informal comments and suggestions about the survey. The comments from the pilot study, for example, helped in rearranging the design of the survey and to group certain questions that have similar formats or designs. The pilot testing also resulted in eliminating some answer choices in favor of a partial-openended multiple choice to make the list of choices shorter. Finally, the pilot testing helped determine that the time to conduct the survey took approximately 10 minutes.

\subsection{Online Distribution of Survey Through Survey Monkey}

The survey was distributed through www.surveymonkey.com, a commonly used tool for conducting academic and non-academic online surveys. The Survey Monkey system allows for the creation of an email message, which was then sent to potential participants. The addresses of potential recipients had to be uploaded to Survey Monkey, which could then track and note if the message to a recipient had bounced. Further, Survey Monkey allowed the message to post a link for recipients to opt-out of receiving any future solicitations from Survey Monkey. 
Survey Monkey also facilitated the transmission of the survey questionnaire via a web link or an Internet address. This could be customized and then sent to potential participants via social media like Facebook and via email as a link. The web link was used to send the survey questionnaire to groups of participants in a "lists serve" or an electronic list of emails with the help of groups like the DIAC, the International Islamic Centre for Reconciliation and Arbitration in Dubai, and the list serve of law firms. The web link address for the survey was as follows: http://www.surveymonkey.com/s/GCCarb/.

\subsection{Data Analysis}

Data analysis was facilitated with the Survey Monkey data analysis online software. The data analyzed by Survey Monkey shows the data in both summary and chart format. The data analysis also shows how many participants answered each question, and how many skipped each question. The data analysis shows the total number of respondents for each question. The questions can also be analyzed by comparison with other answer options. Therefore, those who practised arbitration primarily in the United Kingdom could be looked at separately from those who practised arbitration primarily in the GCC states.

The data collected from the survey were twofold: numerical and textual. Both types of data were compared with the findings in the literature review. This process of triangulation between qualitative and quantitative data was used to confirm and validate the findings. For example, scaled question answers to questions 10-12 resulted in numerical data as to the extent to which judges were familiar with the New York Convention, the UNCITRAL Model Law, and the ICSID Convention. This numerical data was then analysed in light of the answers to the open-ended question concerned which asked for the most likely reasons for the non-enforcement of a foreign arbitral award. Further, the numerical data and textual data are analysed with the conclusions reached from the literature review. 
The interplay between induction and deduction, in other words between data collection and interpretation, was another process of validation of findings but also part of the theory development. In what is known as a process of abduction, the interpretation of the observed data to the best explanation helps to form a tentative theory, which then needs to be confirmed or disconfirmed with the help of further data collections and analysis. The findings from the survey's empirical data were compared and used to weigh with the conclusions drawn from the literature review.

\section{SURVEY RESULTS}

\subsection{Introduction}

The overall results of the survey strengthened some of the observations made by the research from the literature review, while also confirming the necessity of a further study (for generalizability) with a larger survey population and with statistically significant conclusions about the relationships between variables. However, in this survey no observation was made regarding the statistically significant relationships between two variables. Regardless, some direct observations or conclusions can be made from the survey results. Below are the results of each question, followed by a discussion of direct observations or conclusions reached here based on the survey results.

\subsection{Background of Respondents}

There were a total of 41 respondents from the more than 321 survey invitations sent via email and web link. These are the breakdown of the respondents: 


\subsubsection{Profession of the Respondents}

Those involved in arbitration could come from a variety of fields, though most come from the legal profession. Respondents were asked to choose from four types of professions most commonly found among those with experience in arbitration in the GCC states: Attorney (47.5\%), Arbitrator (42.5\%), Legal Consultant (35\%), and Judge $(0 \%)$. Respondents who did not belong to these four professions could choose the "Other" option and specify the profession (25\%). Ten respondents chose the "Other" option and specified the following occupations or professions: Expert witness and the Association of Chartered Certified Accountants (ACCA), procurement and contract manager/engineer, Engineer, Architect, Quantity Surveyor, Engineering Expert, Manager/Support Services of Arbitration Centre, Vice President of Operations, Dispute Resolution (DR), and Teacher. Here is the breakdown by the pre-specified professions:

\section{What is your profession?}

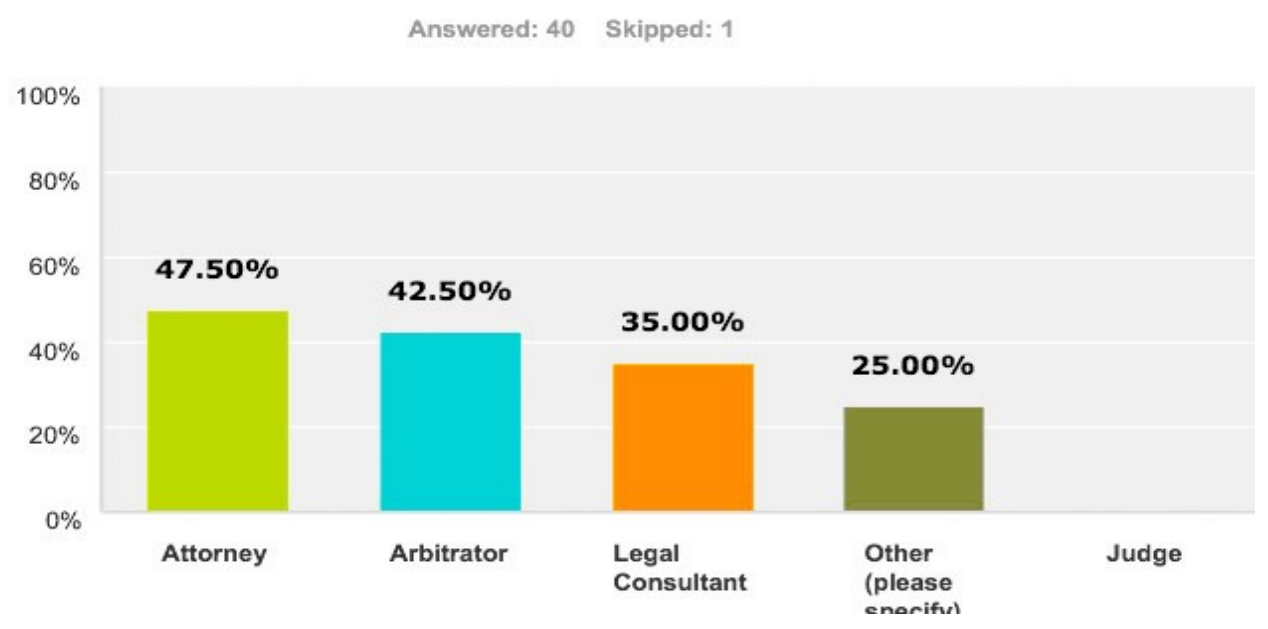

\subsubsection{Arbitration Practice}

Respondents were asked whether they practised in the field of arbitration. There were $87.5 \%$ who practise in the field of arbitration. Here is the breakdown of the respondents: 


\section{Do you practise in the field of arbitration?}

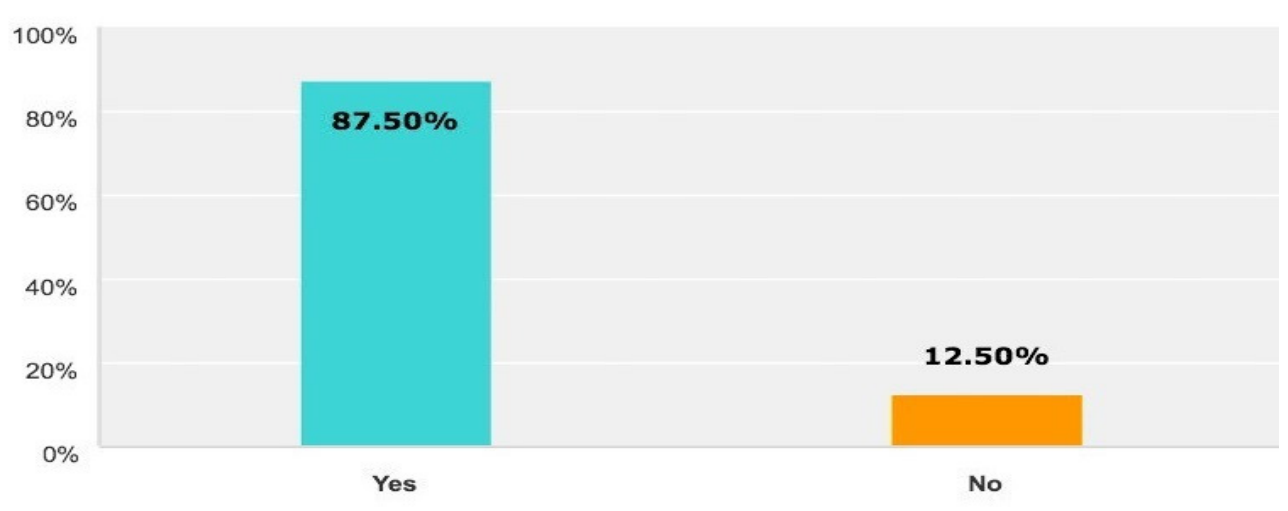

\subsubsection{Experience}

About $80 \%$ of the total respondents have more than 5 years of experience in the field of arbitration. There were $60 \%$ of the respondents with 10 or more years of experience in arbitration and 20\% with 5-10 years of experience.

How many years have you practised your profession?

Answered: 40 Skipped: 1

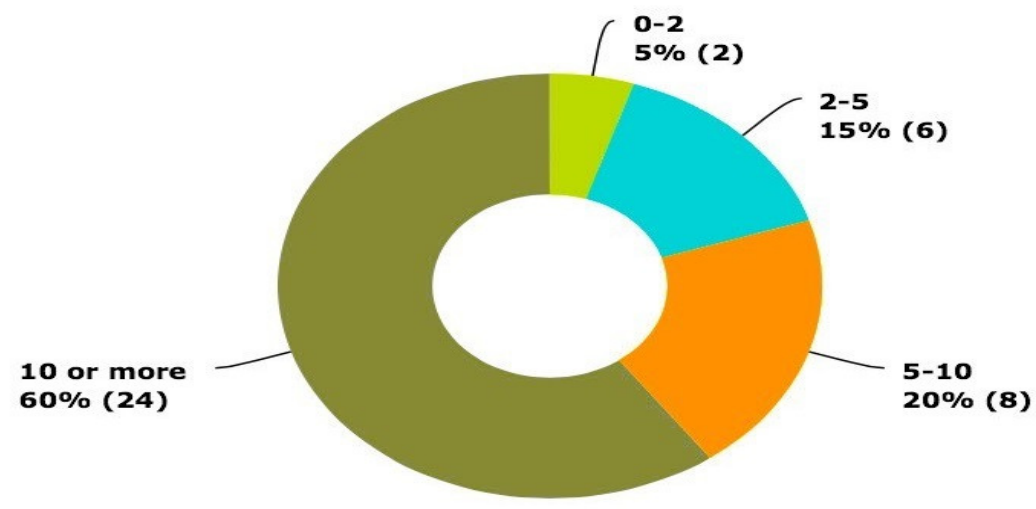

\subsubsection{Language}

The majority of the respondents (95\%) are fluent in English, almost half (45\%) are fluent in Arabic, while some (20\%) are fluent in French. Here is the breakdown of the respondents by language: 


\section{What language(s) are you fluent in? (Please choose at least one.)}

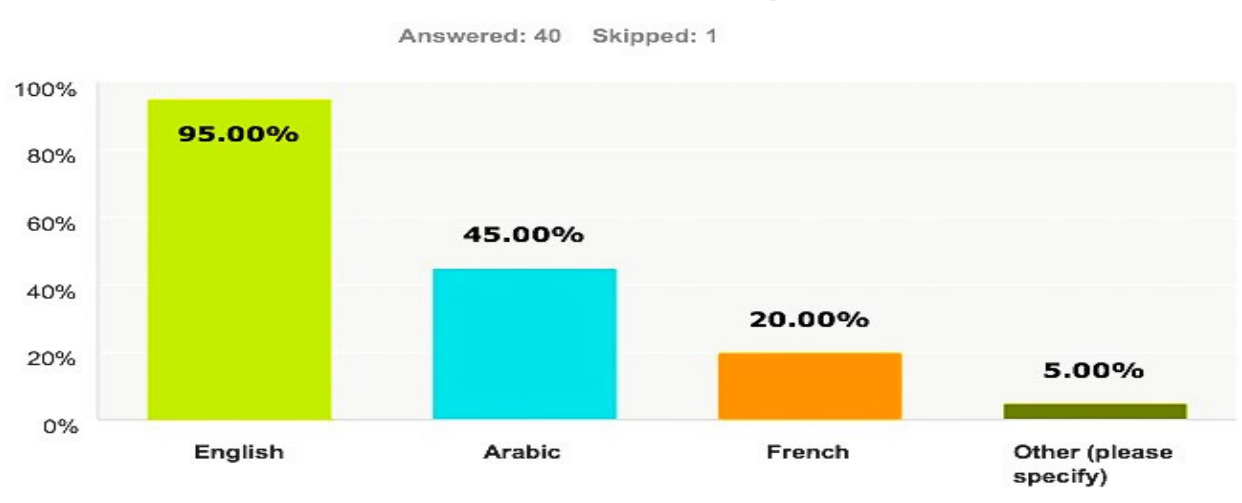

\subsubsection{Country of Practice}

Respondents were also asked in what countries they primarily practised their profession. Many respondents practised in more than one country: regionally (in more than one GCC state) or internationally (in Europe, the Middle East, and/or the GCC). Here is the breakdown of countries:

\section{In which country or countries are you primarily practising your profession? (Choose all answers that apply.)}

Answered: 40 Skipped: 1

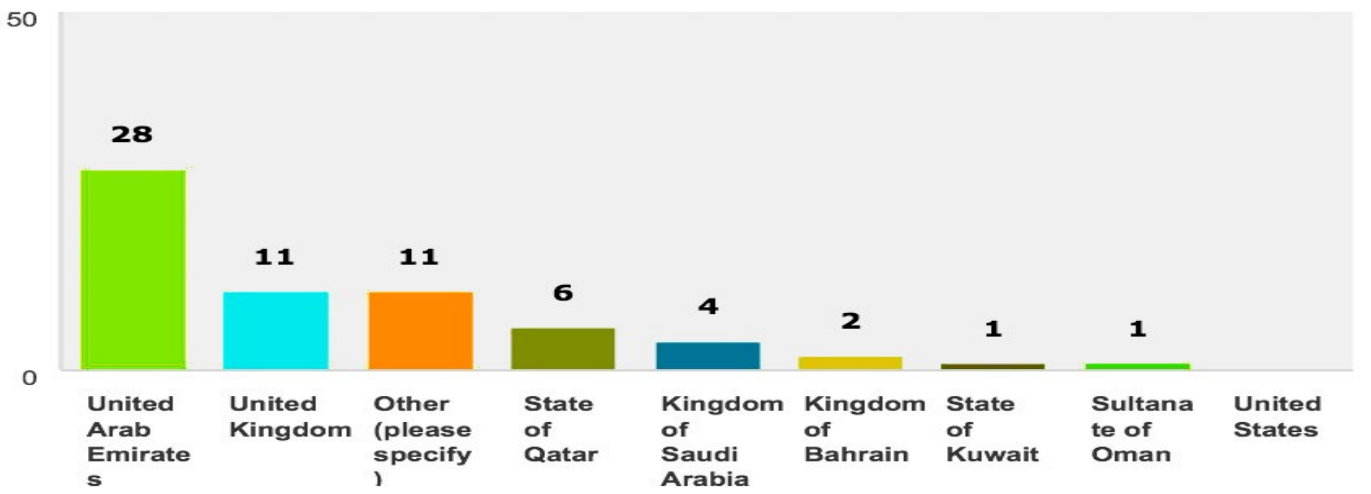

\subsubsection{Experience in the GCC States}

The majority of the respondents $(87.5 \%)$ had experience in the field of arbitration in one or more of the GCC states. 


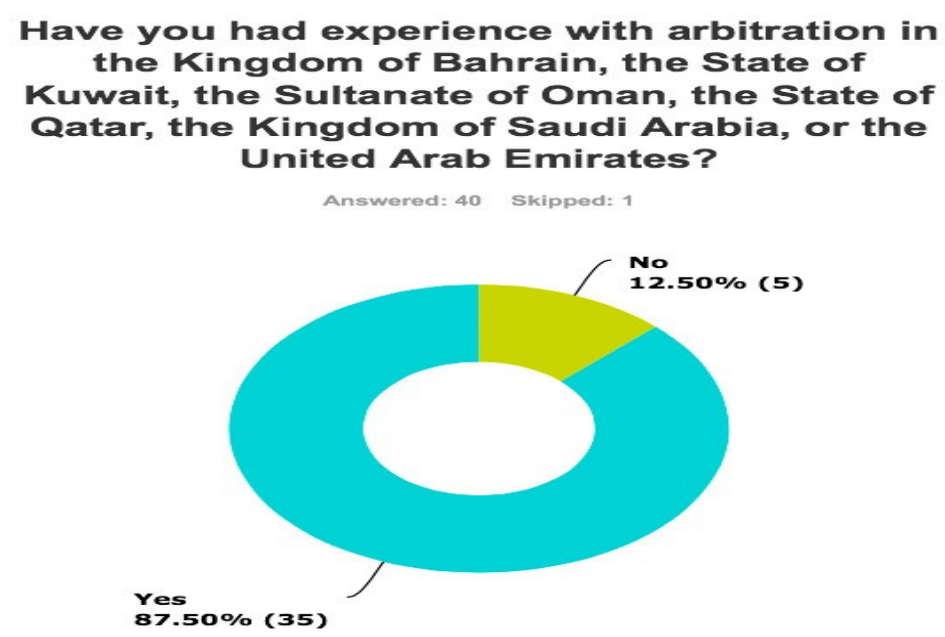

\subsubsection{Shari'a School of Thought or Fiqh}

According to the literature review, the Islamic School of Thought impacted the interpretation of the Shari'a. To determine whether the majority of the school of thought influenced the enforcement of arbitral awards in a jurisdiction, the respondents were asked what School of Thought or Fiqh is followed by the majority of judges and lawyers in their country. Those who were not from an Islamic jurisdiction or who did not primarily practise in an Islamic jurisdiction or any of the GCC states were given the opportunity to state so with a "Not Applicable" choice.

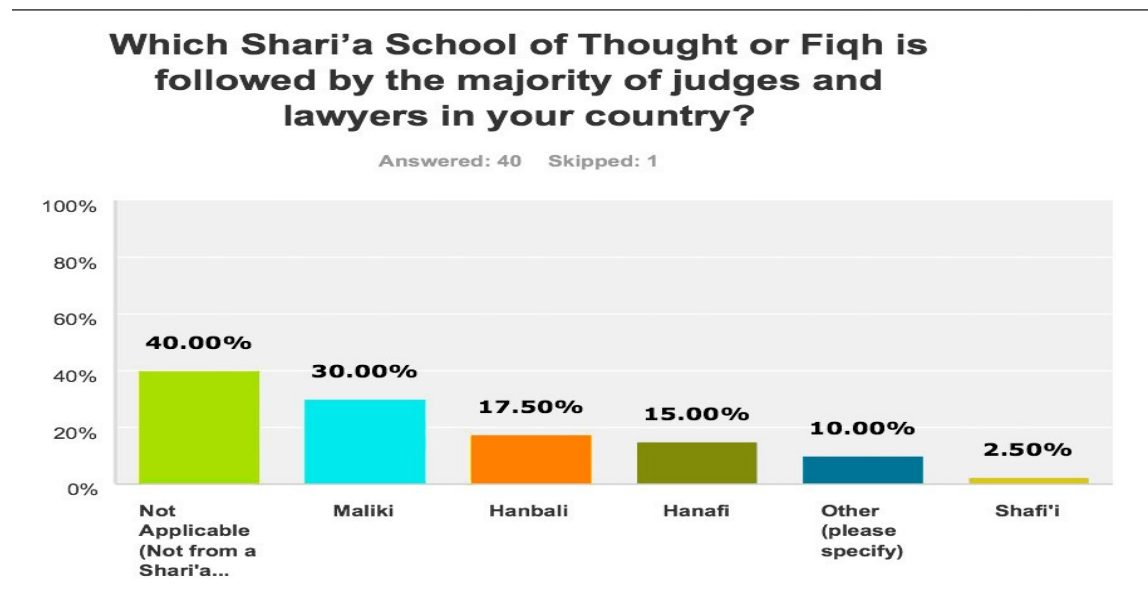




\subsection{Rating}

Respondents were asked to rate a series of issues including (1) how they viewed the friendliness of each of the six GCC states towards the enforcement of a foreign arbitral award; (2) the familiarity of judges in the GCC states with the New York Convention, the UNCITRAL Model Law, and the ICSID Convention; (3) whether the adoption of the UNCITRAL Model Law would benefit Qatar, Kuwait, and the UAE; and (4) how satisfied were the respondents with regard to their country's definition of "domestic award", "foreign award", and "international award."

\subsubsection{Friendliness of GCC states towards foreign arbitral award enforcement}

Of the six GCC states, Bahrain and the UAE were viewed as the friendliest with a similar score of 7.44 out of 10 and 7.43 out of 10, respectively. The KSA, despite the recent passage of the Saudi Arbitration Law of 2012, hailed to bring the KSA in line with international arbitration norms, was still viewed as the least friendly toward enforcement of foreign arbitral awards with the lowest score of 3.44 out of 10 . Here is the breakdown of the result:

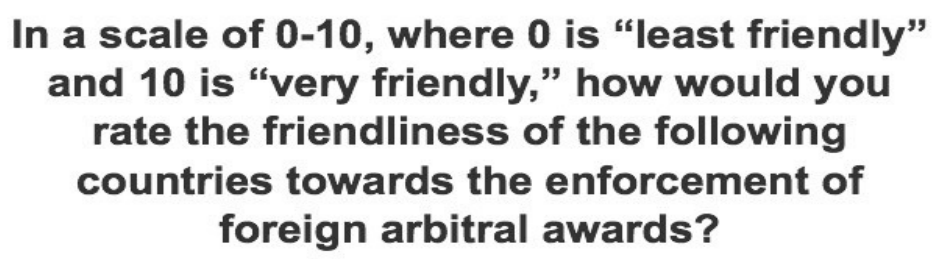

Answered: 37 Skipped: 4

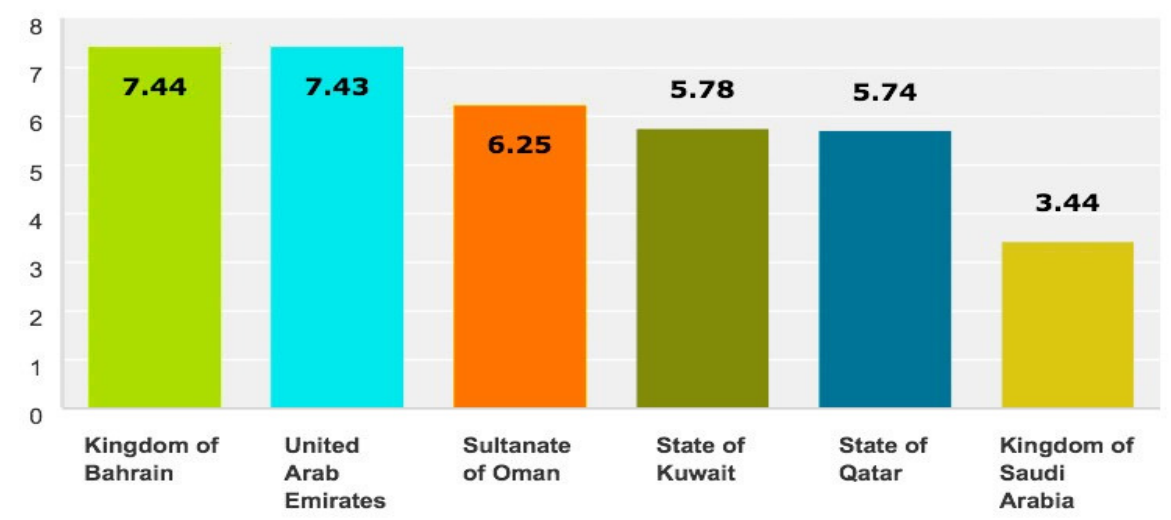




\subsubsection{Familiarity of Judges in the GCC states with international agreements}

Respondents view judges in the GCC states as having low familiarity with international agreements, and especially so with the ICSID Convention which has had very little history in the GCC states. Respondents gave GCC judges a score of 5.86 out of 10 or $58.6 \%$ familiarity with the New York Convention, 4.97 out of 10 or $49.7 \%$ familiarity with the UNCITRAL Model Law, and 3.78 out of 10 or $37.8 \%$ familiarity with the ICSID. This view confirms the conclusions based on the review of the literature that judges are deemed to have little experience with international agreements, and such limited experience may be one of the main reasons for the non-enforcement of foreign arbitral awards. Here is the breakdown of how the respondents viewed the familiarity of judges in the GCC states with the three main international agreements:

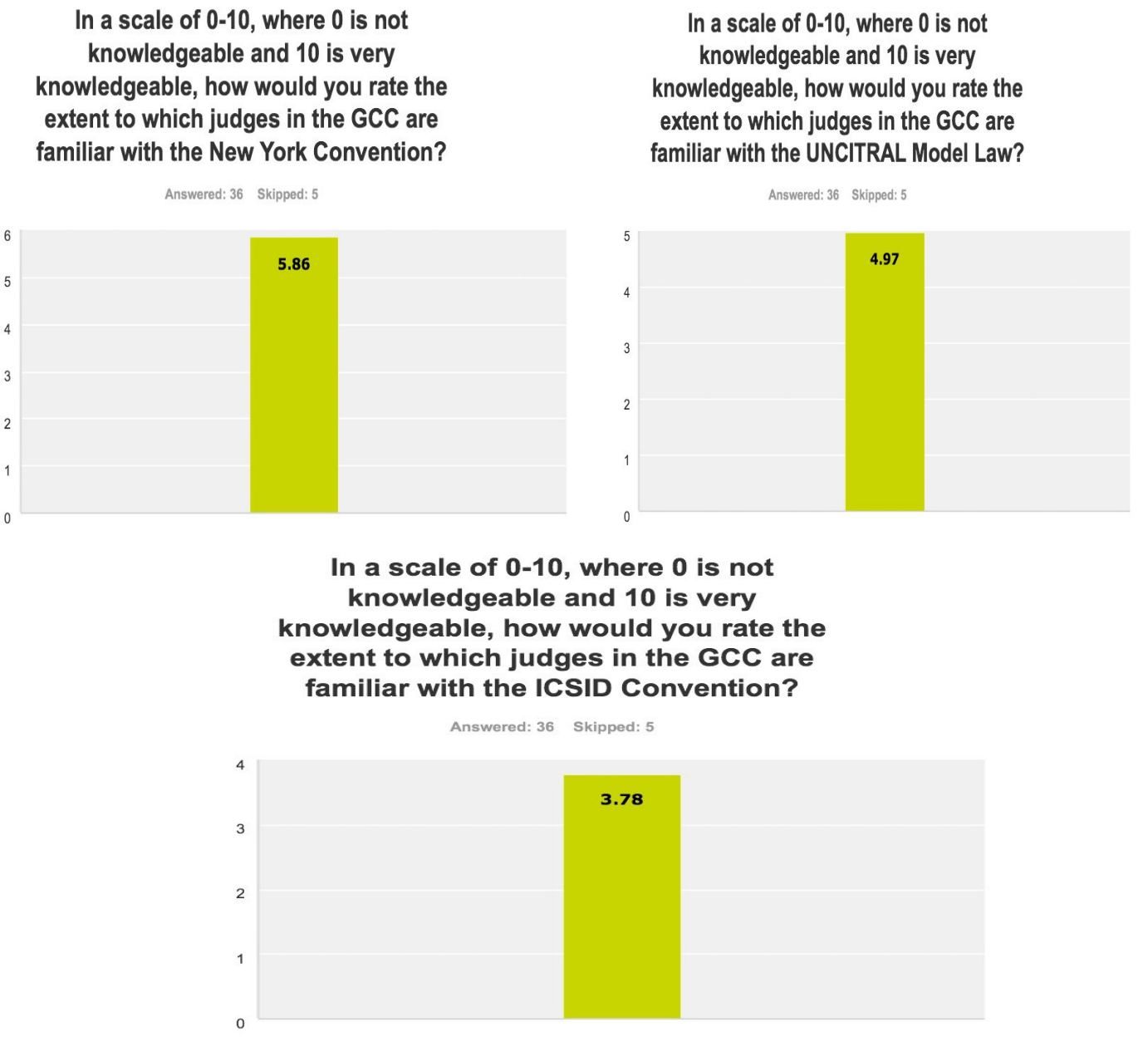




\subsubsection{Benefit of adopting the UNCITRAL Model Law}

The adoption of the UNCITRAL Model Law is usually seen as a positive sign. In the GCC states, only three of six states (Bahrain, Oman, and the KSA) have adopted some version of the UNCITRAL Model Law. Qatar, Kuwait, and the UAE have not yet adopted the UNCITRAL Model Law, and the majority of the respondents viewed that the adoption by these three GCC states of the UNCITRAL Model Law would be beneficial. These results confirm the conclusion and the proposal by the research that all the GCC states ought to adopt the UNCITRAL Model Law, and possibly through a Uniform GCC Arbitration Law. Here is the breakdown of the data:
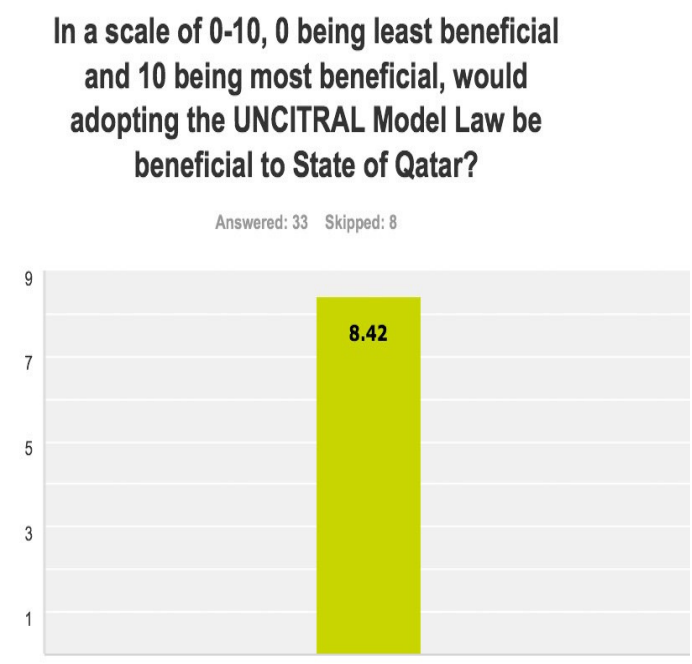

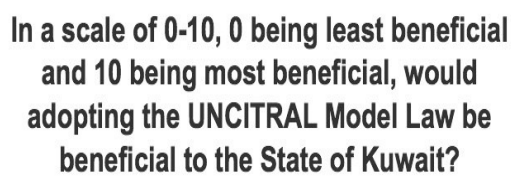

Answered: 33 Skipped: 8

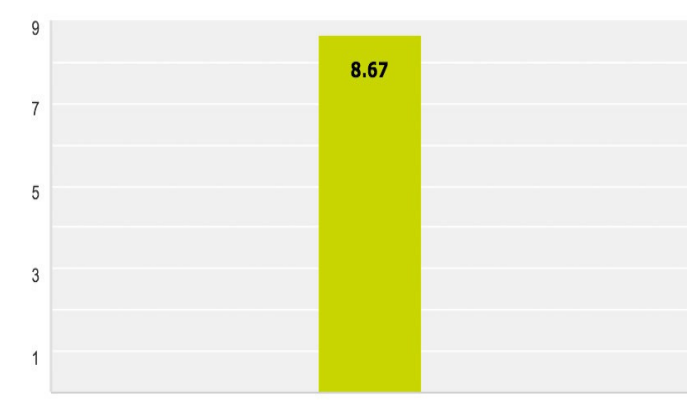

In a scale of $0-10,0$ being least beneficial and 10 being most beneficial, would adopting the UNCITRAL Model Law be beneficial to the United Arab Emirates?

Answered: 33 Skipped: 8

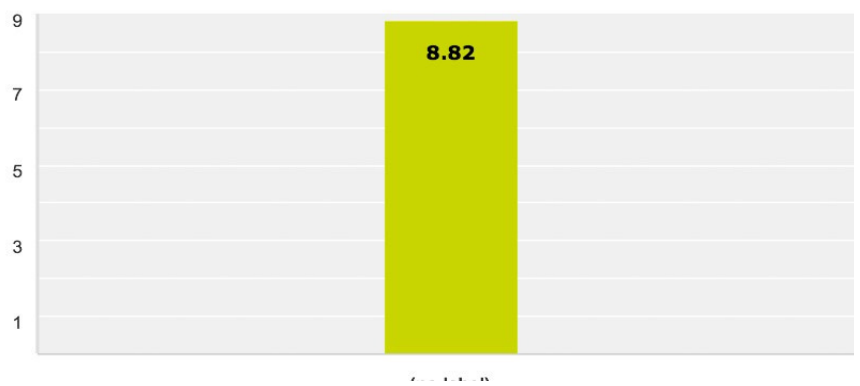




\subsubsection{Definition of foreign, domestic, and international award}

Respondents were also asked to state their satisfaction with their country's definition of foreign, domestic, and international arbitral award. Though the majority of the respondents were generally somewhat satisfied with their country's definition of foreign and domestic arbitral award, the majority of the respondents were not as satisfied with their country's definition of international arbitral award with a lower score of 6.16 out of 10 or a $61.6 \%$ satisfaction rating. Here is how the data breaks down:

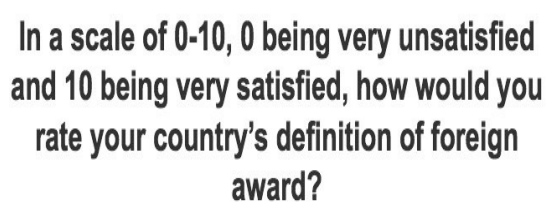

Answered: 33 Skipped: 8

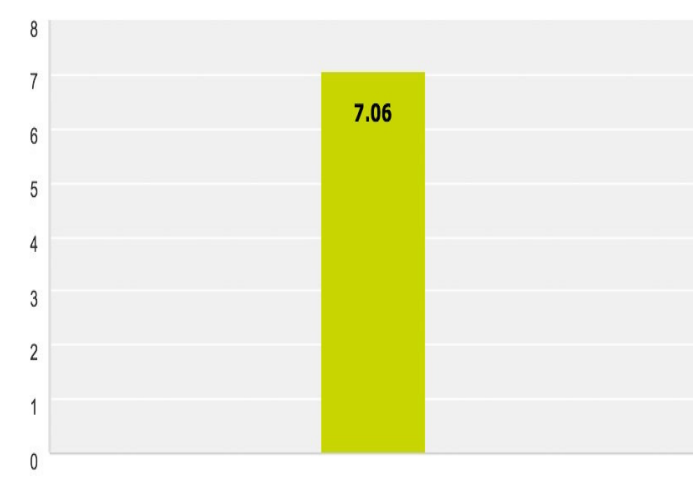

In a scale of $0.10,0$ being very unsatisfied and 10 being very satisfied, how would you rate your country's definition of domestic award?

Answered: 33 Skipped: 8

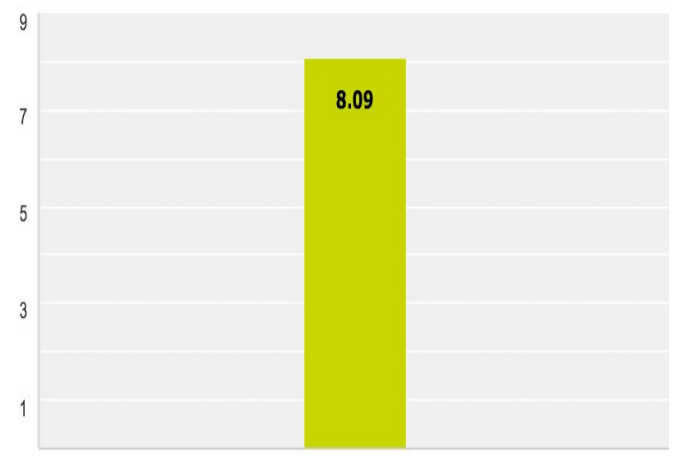




\section{In a scale of $0-10,0$ being very unsatisfied and 10 being very satisfied, how would you rate your country's definition of international award?}

Answered: 32 Skipped: 9

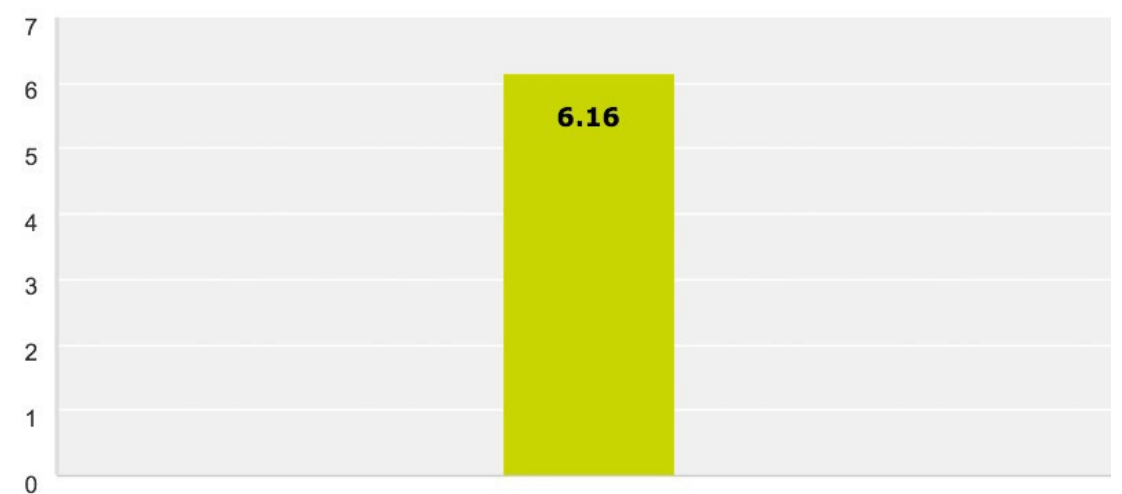

\subsection{Reasons for Non-Enforcement of a Foreign Arbitral Award}

Respondents were asked an open-ended question as to the most likely reason for the non-enforcement of a foreign arbitral award. The question aimed to solicit ideas from respondents as to the reasons for non-enforcement, identify the most common reasons for non-enforcement, and to compare the most common reasons for enforcement to those identified in the literature review.

The most common responses using textual analysis were grouped together. The highest number of common responses is eleven (11) that identify public policy as the most likely reason for non-enforcement. The second highest number of common responses had a total of six (6) responses that identify the lack of familiarity or knowledge with international arbitration, the New York Convention, or some form of judicial activism or hostility as the reason for non-enforcement. The third highest number of common responses had five (5) responses that identify the failure of the arbitration statute as the reason for non-enforcement. The fourth highest number of common responses had four (4) responses identifying jurisdictional issues as the reason for non-enforcement. The fifth highest number of common responses had three (3) responses that identify social or political reason for non-enforcement. The rest of the 
remaining nine (9) responses varied and included one response, which stated that the Shari'a is the most common reason for non-enforcement.

\subsection{A Uniform GCC Arbitration Law?}

One of the key purposes of this study is to propose a set of rules for a prospective Uniform GCC Arbitration Law. It is, however, intended to clarify whether a Uniform GCC Arbitration Law had support from arbitration practitioners and experts in the GCC States. The research reveals that the majority of respondents at $81.25 \%$ are in favour of a Uniform GCC Arbitration Law. Here is how the numbers break down:

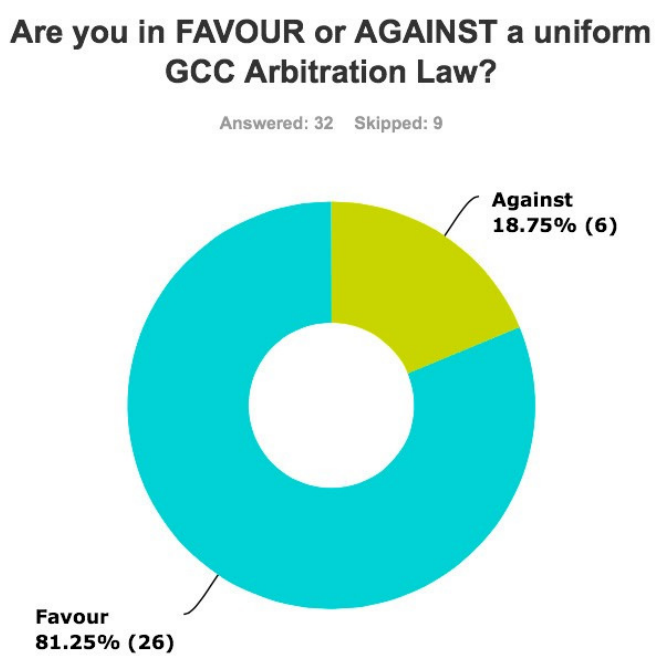

\subsection{Conditions for Enforcement}

One of the common criticisms found by the research in the literature review is that states like the UAE continue to apply domestic arbitration rules for the enforcement of foreign arbitral awards. Courts in the GCC states may, for example, require conditions for the enforcement of foreign arbitral awards that should only be applicable to domestic arbitral awards, and therefore leading to the non-enforcement of an arbitral award. Respondents were asked two sets of questions regarding the conditions for enforcement. 
3.5.1. Whether domestic or foreign arbitral awards should have the same or different conditions for enforcement.

The majority of the respondents at $62.50 \%$ viewed that domestic and foreign arbitral awards ought to have the same conditions for enforcement. This was not the expected answer, but perhaps respondents viewed the question to address the equal treatment of domestic and foreign awards. Here is the breakdown of the answers:

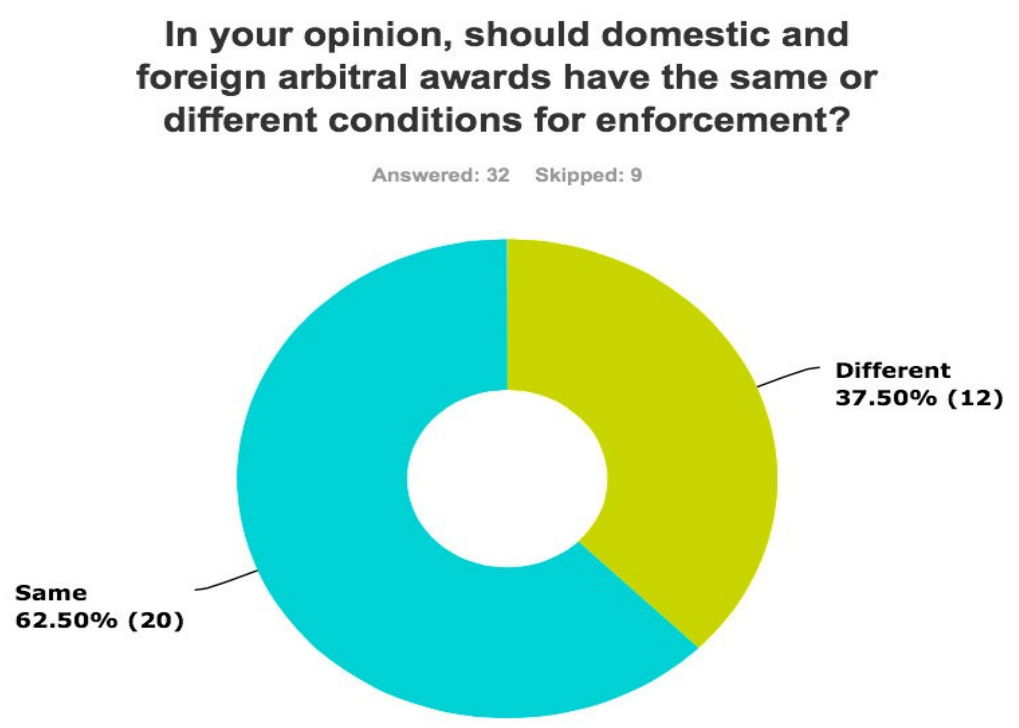

3.5.2. Whether conditions for enforcement for domestic arbitral awards equally apply in practice to foreign arbitral awards.

Consistent with their answers to the previous question, the majority of respondents at $75 \%$ viewed that the conditions for enforcement of domestic and foreign arbitral awards were not equally applied. 


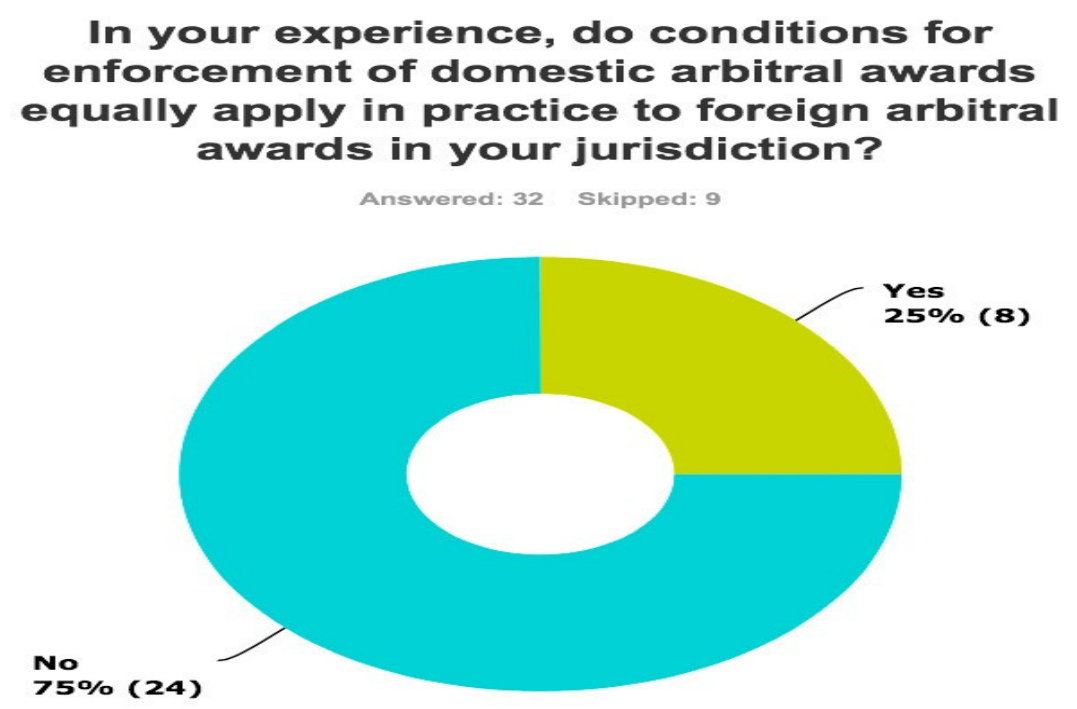

\subsection{The Effect of the Shari'a}

One of the central themes in the research was to determine the impact of the Shari'a on the enforcement of arbitral awards. The research concludes from the review of the literature that the Shari'a is actually more consistent with the New York Convention as viewed by Western practitioners. The survey was then used to determine how those practising in the field of arbitration view the role of the Shari'a in the enforcement of arbitral awards, specifically with regard to public policy and whether riba [interest] ought to be allowed in arbitral awards. In this regard, respondents were asked three questions.

\subsubsection{Conflict between the New York Convention and the Shari'a}

Respondents were asked about their knowledge as to the interplay between the New York Convention and the Shari'a. When asked whether the New York Convention or the Shari'a would prevail in a conflict, the respondents were split with $53.13 \%$ who stated that the New York Convention would prevail, while a staggering $46.88 \%$ stated that the Shari'a would prevail. There were those who explained further their choice, and 
only two comments correctly stated that there ought to be no conflict between the New York Convention and the Shari'a. Here is how the numbers break down:

\section{In a conflict between the New York Convention and the Shari'a, which prevails in your jurisdiction?}

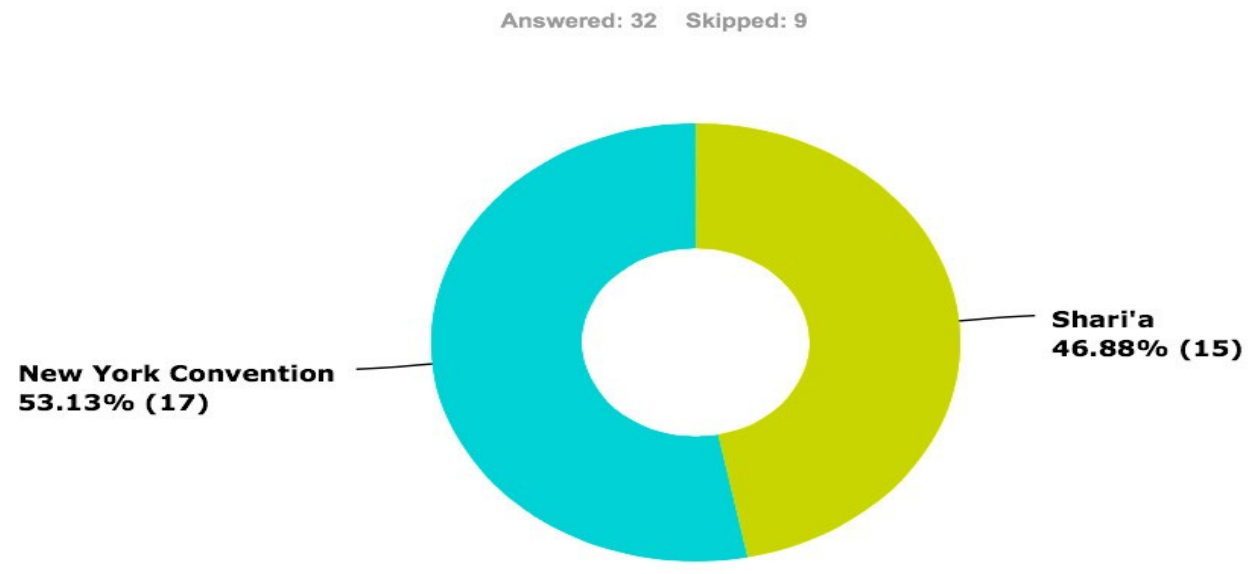

\subsubsection{Shari'a and public policy}

One of the main issues addressed by the research was the extent to which the Shari'a ought to apply in determining public policy. A review of the literature reveals that the concerns of the Shari'a with regard to public policy were largely consistent with the New York Convention, and would only seem to deviate from international arbitration norms with regard to a few substantive Shari'a public policies that are fundamentally considered haram [prohibited]. Public policies under the Shari'a that related to procedures were largely consistent with international arbitration norms. The research, concluded that the Shari'a ought to be applied only when the arbitral award concerned a fundamental Shari'a principle, largely limited to the prohibitions on the riba [interest] and gharar [uncertainty] and when the subject of the agreement deals with alcohol and/or pork. In this regard, respondents were asked when the Shari'a ought to apply when determining public policy. The majority of the respondents at $48.39 \%$ answered that the Shari'a ought to apply when a violation of a fundamental Shari'a 
principle has been established, a view that supports the conclusion reached by the research. Here is a breakdown of the numbers:

\section{In your opinion, when should judges or arbitrators apply the Shari'a when determining whether public policy has been violated? (Please choose one.)}

Answered: 31 Skipped: 10

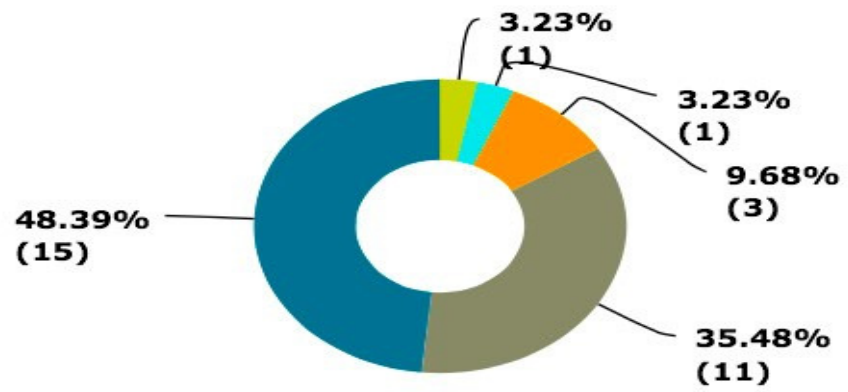

Whenever a violation of a fundamental Shari'a principle could potentially arise

Whenever a violation of any Shari'a principle has been established Always

Never

Whenever a violation of a fundamental Shari'a principle has been established

\subsubsection{When should interest (riba) be allowed?}

The survey also sought to determine how those in the field of arbitration in the GCC states view interests in an arbitral award. The views taken by the respondents on the subject of interest are diverse, only finding commonality among those who do not speak Arabic and who do not primarily practise in the GCC states. Here is the breakdown of the numbers: 


\title{
Should interest be allowed in an arbitral award?
}

\author{
Answered: 31 Skipped: 10
}

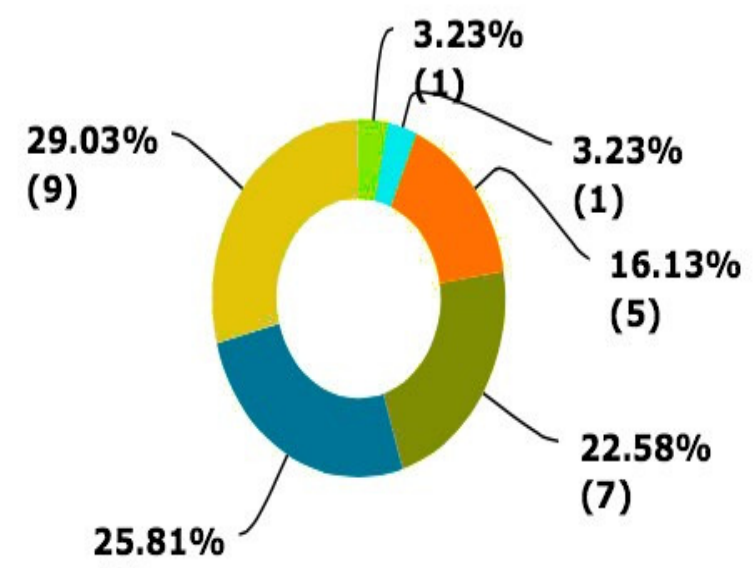

(8)

No, according to the prohibition on the riba

No, unless the parties are all non-Muslims

Other (please specify)

Yes, without limitations

Yes, but limited to a certain percentage

Yes, according to the contract

\subsection{Testing the Proposed Rules}

The survey was also used as a tool to test whether a set of rules for a prospective Uniform GCC Arbitration Law proposed by this study was reasonable. Therefore, the language of the six proposed rules was stated individually in the survey, and respondents were asked whether they agreed or disagreed with the entire statement. The majority of the respondents agreed with the six statements for the proposed rules. Here are the results for each of the proposed rules: 
Please consider the following statement(s): A domestic arbitral award refers to all arbitral awards not falling under the definition of a foreign arbitral award, unless otherwise expressly stated by these arbitration rules and/or any legislation. The New York Convention shall not apply to the enforcement of a domestic arbitral award.

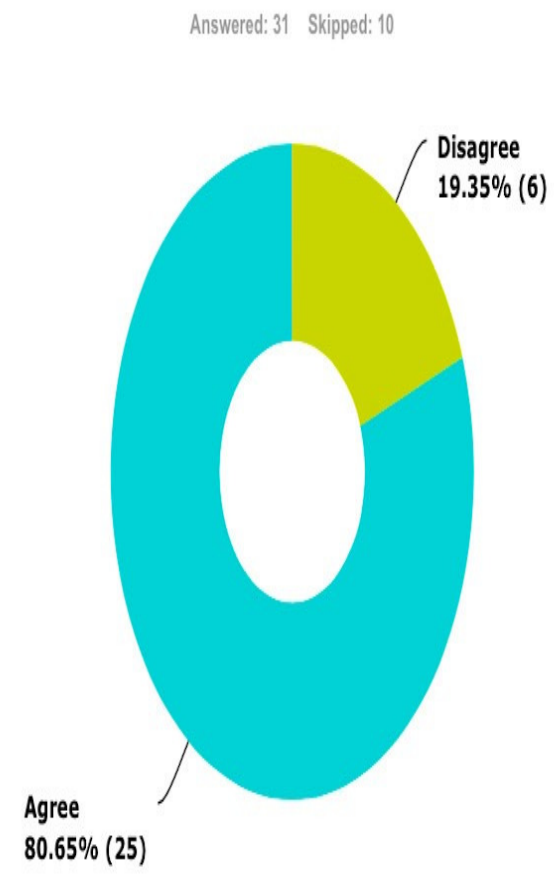

Please consider the following statement(s): A foreign arbitral award is an arbitral award that was made in the territory of a State, such state being a signatory to the New York Convention if required by a GCC state, other than the State where the recognition and enforcement of such arbitral award is sought, and arising out of differences between persons, whether physical or legal. The New York Convention shall apply to the enforcement of all foreign arbitral awards, including the interpretation of this provision. Do you agree or disagree with the entire statement?

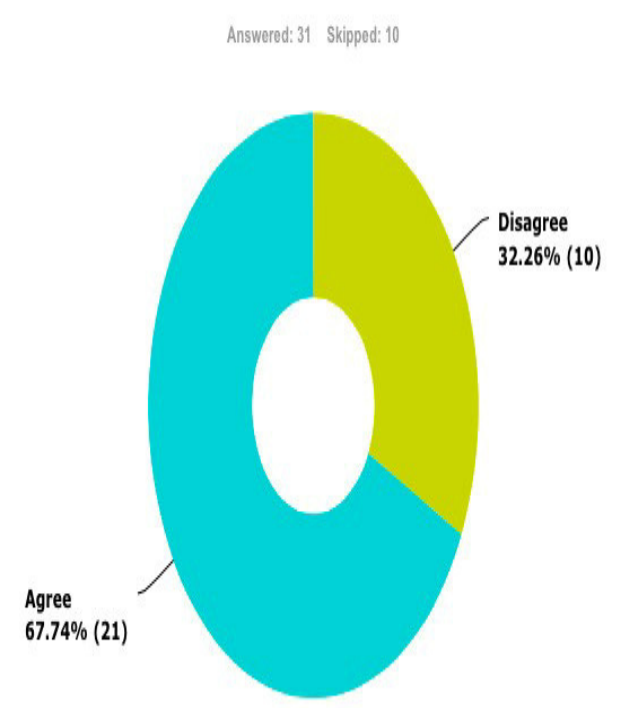


Please consider the following statement(s): An arbitral award is international when (1) the parties to the arbitration have places of business in different states; (2) the location of one of the party's places of business is in a state, other than the State where the recognition and enforcement of such awards are sought; (3) at least one of the party's countries of business is different to the place where a substantial part of the commercial relationship's obligations was performed; or (4) the parties agree that the subject matter of the arbitration agreement relates to more than one country. An international award shall be deemed as a foreign award and shall be governed by the New York Convention. Do you agree or disagree with the entire statement?

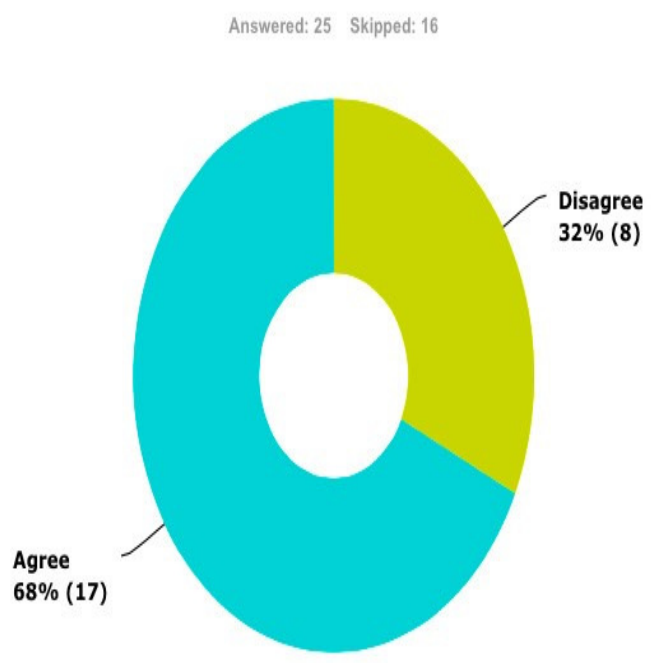

Please consider the following statement(s):

The conditions to the enforcement of a domestic arbitral award shall not apply to a foreign or international arbitral award. Do you agree or disagree with the entire statement? Answered: 31 Skipped: 10

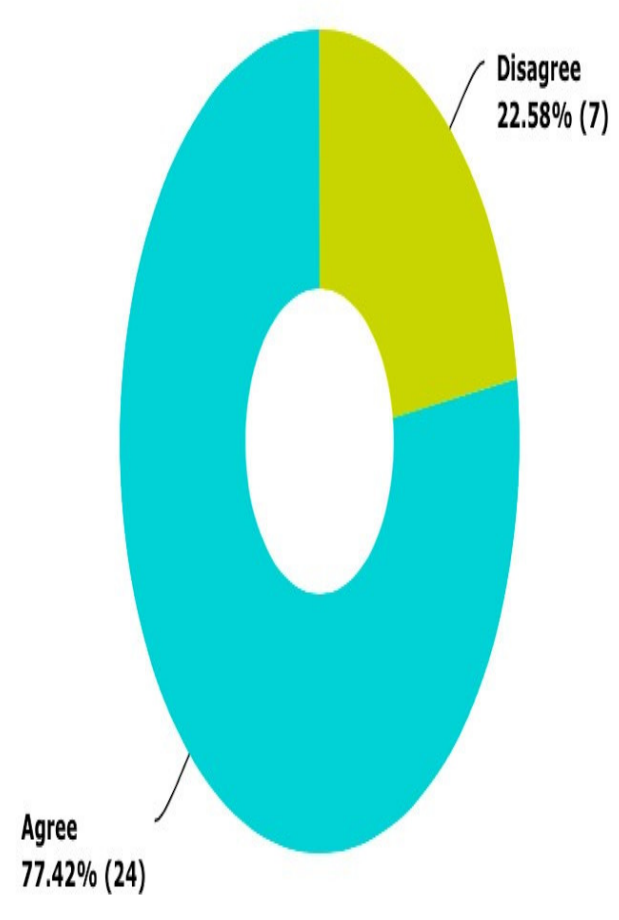


Please consider the following statement(s): A court may only refuse enforcement of a foreign arbitral award or annul a foreign arbitral award under the grounds stated in the New York Convention and pursuant to the rule relating to the interpretation of public policy as a ground for nonenforcement or annulment of an arbitral award. A court that refuses to enforce a foreign arbitral award or annuls a foreign arbitral award on grounds not listed under the New York Convention or based on public policy must provide to the parties, in a written judgment, an explanation of its reasoning and decision, including the specific legislative or case law source of such grounds or public policy. Do you agree or disagree with the entire statement?

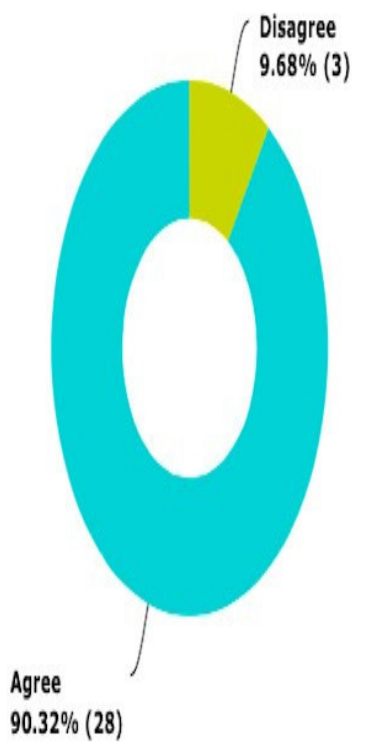

Please consider the following statement(s): Courts must interpret public policy narrowly, and should only be granted as a defence if the public policy concerns an essential or fundamental state interest. The Shari'a shall qualify as an essential or fundamental state interest for purposes of public policy, but only those public policy embodied by the Shari'a that are expressly stated in the Quran, Sunna, Qiyas, and ljma, those that are haram, and those that are stated as fundamental to the Shari'a by a majority of the Shari'a scholars. Whenever there is no clear consensus as to a public policy under the Shari'a, the court shall weigh the determination of the existence of such public policy on the public policy in favour of enforcement of an arbitral award under the New York Convention. Do you agree or disagree with the entire statement?

Answered: 31 Skipped: 10

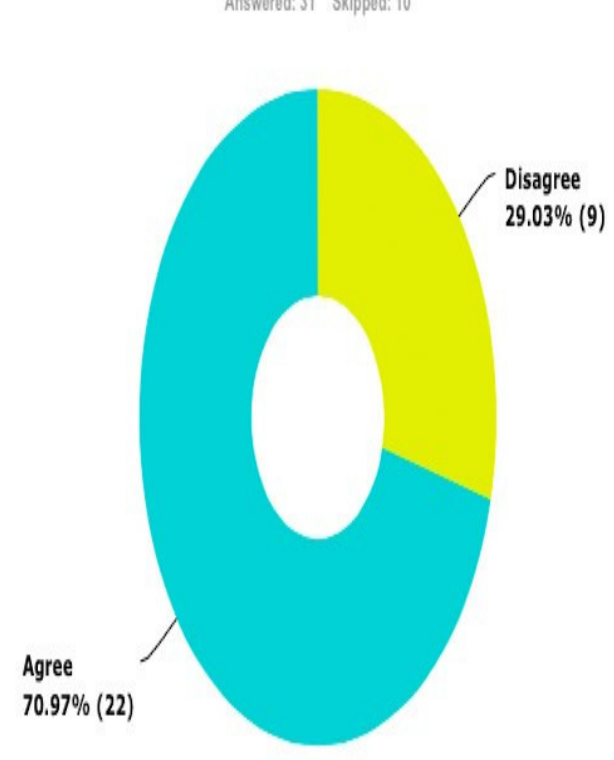




\section{An Appraisal}

The overall results of the survey confirmed many of the conclusions made by the research based on the review of the existing literature. The survey was also used as a tool to test the foregoing six rules relating to the enforcement of foreign arbitral awards in a prospective Uniform GCC Arbitration Law proposed in the study. In the end, the survey corroborated the conclusions drawn from the literature review.

In the survey, respondents were asked to rate their satisfaction with their country's definition of domestic, foreign, and international arbitral awards. The respondents from the six GCC states were most satisfied with their country's definition of domestic arbitral award at 8.09 out of 10 or $80.9 \%$ satisfaction, less satisfied with their country's definition of foreign arbitral award at 7.06 out of 10 or $70.6 \%$ satisfaction, and least satisfied with their country's definition of international arbitral award at 6.16 out of 10 or $61.6 \%$ satisfaction. The survey suggests that the GCC states could improve their arbitration laws by adopting a uniform set of definitions, especially for international and foreign arbitral awards. What is surprising from the survey is the lower satisfaction rating for the definition of a "foreign arbitral award," which ought to be consistent with the New York Convention's definition.

International arbitral awards could be governed by the UNCITRAL Model Law, the national law of a GCC state, and implicitly by the New York Convention as a nondomestic arbitral award. Most GCC states, however, have not expressly addressed international arbitral awards. Only Bahrain and Oman have national legislation specifically covering and defining international arbitral awards. It is not surprising, therefore, that the majority of the respondents in the survey only gave a 6.16 out of 10 or a $61.6 \%$ satisfaction when asked to rate their country's definition of international arbitral award.

One of the questions that arbitration practitioners in the GCC states continue to grapple with, deals with the reconciliation of a treaty obligation as with the New York Convention and the Shari'a. In the survey, respondents were asked which would prevail if there is a conflict between the New York Convention and the Shari'a. The respondents were largely divided on the question with $53.13 \%$ correctly stating that the 
New York Convention would prevail, while $46.88 \%$ stated that the Shari'a would prevail. There were those who explained further their choice, and only two comments correctly stated that there ought to be no conflict between the two. Answering the question is quite tricky, as it requires knowledge of both the New York Convention and the Shari'a, especially the Shari'a. After a review of the literature, this research concludes that the Shari'a and the New York Convention would not actually conflict since the New York Convention allows for the public policy defence under which the Shari'a would qualify. Further, the Shari'a requires all Muslims to honour their contract $^{46}$, which the majority of Shari'a scholars have interpreted to mean that Muslims have an obligation to follow international agreements.

Whether the New York Convention actually prevails in practice is another matter, and the split among practitioners in the GCC states on the same question is a sign that there will be instances when GCC states' judges would ignore the New York Convention for fear of violating the Shari'a.

In the survey, respondents were asked whether domestic and foreign arbitral awards should have the same or different conditions for enforcement. The majority of the respondents at $62.50 \%$ prefer that the conditions for enforcement for domestic and foreign arbitral awards be the same, while only $37.50 \%$ prefer different conditions for enforcement. This view suggests that the majority of arbitration practitioners in the GCC states favour an enforcement procedure that treats both domestic and foreign arbitral awards equally. When respondents were asked whether conditions for enforcement of domestic arbitral awards equally apply in practice to foreign arbitral awards, the majority of the respondents at $75 \%$ answered "No", while only $25 \%$ answered "Yes." The GCC states not only have different conditions from one another, but also between domestic and foreign arbitral award enforcement.

Interestingly, the ratings by the respondents to the survey of the GCC states' friendliness toward arbitration do not seem to tally with the GCC states' laws for challenges to enforcement. In other words, one might expect that Bahrain and the UAE, as the highest rated GCC states in the survey, would share similar grounds for

\footnotetext{
${ }^{46}$ See M. Hamid, 'Islamic Law of Contract or Contracts', Journal of Islamic and Comparative Law, 3 (1969), pp. 1-11; N. Mohammed, 'Principles of Islamic Contract Law', Journal of Law and Religion, 6 (1988), pp. 115-116.
} 
challenges to the enforcement of foreign arbitral awards and that both GCC states would have limited grounds for challenging enforcement. However, these two GCC states do not seem to differ significantly from the remaining GCC states with regard to common features in potential challenges to the enforcement of foreign arbitral awards.

In the survey, respondents were asked an open-ended question as to the most likely reason for the non-enforcement of a foreign arbitral award in the GCC states. The question aimed to solicit ideas from respondents as to the reasons for nonenforcement, identify the most common reasons for non-enforcement, and to compare whether the most common reasons for enforcement are the same or similar to those identified by the research.

The survey also shows a sign that many arbitration practitioners are aware of the balance that must be made between public policy and the Shari'a. Respondents were asked when judges or arbitrators should apply the Shari'a when determining whether public policy has been violated. The majority of the respondents at $48.93 \%$ want judges or arbitrators to apply the Shari'a when determining whether public policy has been violated only when a violation of a fundamental Shari'a principle has been established. Still, some respondents at $35.48 \%$ voted that the Shari'a should "Never" be applied when determining whether public policy has been violated. These two competing views on the role of the Shari'a in determining public policy may also indicate the divide in the judiciary when faced with a public policy challenge based on the Shari'a.

The survey also asked respondents whether interest should be allowed in an arbitral award. The question was asked in the survey to determine how those in the field of arbitration in the GCC states view interests in an arbitral award. The majority of the respondents, amounting to a total of $77.42 \%$ answered that interest should be allowed, while only a total of $22.51 \%$ answered that interest should not be allowed. Those who were in favour of allowing interest, however, differed in three ways as to the extent to which interest ought to be allowed. Of those who are in favour of allowing interest in an arbitral award, $29.03 \%$ favoured interest according to the contract, $25.81 \%$ favoured interest but limited to a certain percentage, and $22.58 \%$ are in favour of interest without limitations. 
In the survey, respondents were asked to rate in a scale of $0-10$, the friendliness of the six GCC states towards the enforcement of foreign arbitral awards. The respondents gave Bahrain and the UAE the highest rating with 7.44 out of 10 and 7.43 out of 10, respectively. The KSA, despite its passage of the Saudi Arbitration Law of 2012, was still rated the least friendly toward the enforcement of foreign arbitral awards with a rating of 3.44 out of 10 . Oman was rated with 6.25 out of 10 , Kuwait with 5.78 out of 10, and Qatar with 5.74 out of 10. Interestingly, Bahrain and the UAE have different approaches with regards to setting aside, where Bahrain follows strictly the UNCITRAL Model Law, while the UAE has not yet adopted the UNCITRAL Model Law. In other words, the survey seems to indicate that the perception of the friendliness of a GCC state towards the enforcement of a foreign arbitral award may not necessarily be dictated by the GCC state's rules on setting aside an arbitral award. Yet, it is possible that Bahrain was rated high as to "friendliness" because of its loyal adoption of the UNCITRAL Model Law.

In the survey, the majority of respondents viewed that the adoption by Kuwait, Qatar and the UAE of the UNCITRAL Model Law would be beneficial. The results were similar for the three states when asked whether adopting the UNCITRAL Model Law would be beneficial for each of these GCC states with respondents stating that it would be 8.42 out of 10 or $84.2 \%$ beneficial to Qatar, 8.67 out of 10 or $86.7 \%$ beneficial to Kuwait, and 8.82 out of 10 or $88.2 \%$ beneficial to the UAE. These results confirm the conclusion and the proposal by the research that all the GCC states ought to adopt the UNCITRAL Model Law and a Uniform GCC Arbitration Law.

There have been numerous calls in the GCC states for a uniform arbitration law, and efforts have been made to propose a draft Uniform GCC Arbitration Law. ${ }^{47}$ In the survey, respondents were asked whether they were in favour of or against a Uniform

\footnotetext{
${ }^{47}$ N Kawach, 'Gulf states plan single arbitration law' (22 Aug 2009), Emirates Business 24/7, available at http://www.emirates247.com/eb247/economy/uae-economy/gulf-states-plan-single-arbitration-law2009-08-22-1.30548 (last accessed 20 Feb 2014); A Sheta, 'GCC Unified Arbitration Draft Law', 1 J Arab Arb 92, 93 (2009); Satish Kandady, 'Unified GCC Arbitration Law Set to Take Effect Next Year' The Peninsula (Doha, 7 April 2009)

$\square$ http://www.thepeninsulaqatar.com/Display_news.asp?section=business_news\&month=april2009\&file= business_news2009040722050.xml $\square$ accessed 21 February 2014; 'Draft of Unified Law for Arbitration in States of Gulf Cooperation Council' (2009) 1 J Arab Arb 559, 573 (“QICA Draft Unified Law”).
} 
GCC Arbitration Law, and $81.25 \%$ were in favour while only $18.75 \%$ were against it. The survey shows that there is a large support among the GCC states arbitration practitioners for creating uniformity in the arbitration laws of the GCC states.

It is interesting to note that public policy was identified in the survey as the most common reason for non-enforcement of foreign arbitral awards, when public policy is a common ground among the GCC states. The research concludes that the Shari'a does affect the enforcement of foreign arbitral awards with regard to the public policy defence. This research reveals, however, that a closer look at the public policy under the Shari'a shows more compatibility than differences with the public policy under international and regional agreements and the public policy of each of the GCC states. There is, therefore, something else going on behind the application of the public policy defence, and this research shows that judicial activism is the culprit behind the use of the Shari'a to deny enforcement based on public policy, even when there is no public policy violation.

Suffice it to say that while Shari'a public policy could be harmonised with international arbitration norms, save for very specific fundamental issues under the Shari'a such as those which are haram [prohibited], there seems to be a practice in the courts of the GCC states to refuse enforcement of foreign arbitral awards based on Shari'a public policy, which is corroborated by experienced arbitration practitioners in the GCC states through the survey. In this sense, the Shari'a does indeed affect the enforcement of foreign arbitral awards.

\section{Concluding Remarks}

Overall, the survey corroborates the conclusions made by the research based on the literature review, and also highlights the need for further surveys on the matter for generalizability and to fully comprehend the sources of the challenges to the enforcement of foreign arbitral awards in the GCC states. The survey respondents also agreed with all the statements proposed in the survey as a set of rules relating to the enforcement of foreign arbitral awards for a prospective Uniform GCC Arbitration Law. There thus remains a good prospect of such a uniform law in the GCC states. This 
modest research tests the water of the arbitration scene in the GCC states on the issues of and challenges to the enforcement of foreign arbitral awards. However, a major multilingual survey involving a larger population of the GCC states' arbitration practitioners and experts should be conducted for a wider picture. This is left for another occasion!

\section{BIBLIOGRAPHY}

\section{Books and Articles}

Alassaf, Abdullah and Zeller, Bruno, 'The Legal Procedures of Saudi Arbitration Regulations 1983 and 1985' (2010) 7 MqJBL 170.

Al Baharna, Husain, 'The Enforcement of Foreign Judgments and Arbitral Awards in the GCC Countries with Particular Reference to Bahrain' (1989) 4 Arab LQ 332.

Alezri, Moussa, 'The Role of the Omani Judiciary in Supporting Arbitration' (2010) 2 J of Arab Arb 26.

Al-Jerafi, Wasim, 'Yemen's Ratification of the New York Convention: An Analysis of Compatibility and the Uniform Interpretation of Article V(1)(A) and V(2)(B)' (DPhil thesis, University of Leicester 2013).

Almutawa, Ahmed and Maniruzzaman, AFM, 'The UAE's Pilgrimage to International Arbitration Stardom - A Critical Appraisal of Dubai as a Centre of Dispute Resolution Aspiring to be a Middle East Business Hub' (2014) J World Inv Trade 15, 193-244.

Alrashid, Meriam and others, 'International Arbitration in the Middle East: A Case Study of Qatar' The International Dispute Resolution News (Fall 2009) vol 1, No 1.

Al-Sanhouri, Abd Al-Razzaq, Study on the new civil law [Al Wassit fi Sharh Al Qanun Al Madani Al Jadid] (Ahmad Al-Maraghi ed, 2007) vol 1, 300 et seq.

Alsheikh, Essam, 'Court Intervention in Commercial Arbitral Proceedings in Saudi Arabia: A Comparative Analytical Study of Shari'a Based Statutes and International Arbitral Practises' (DPhil thesis, University of Portsmouth 2011). 
Al-Siyabi, Mohamed, 'A Legal Analysis of the Development of Arbitration in Oman with Special Reference to the Enforcement of International Arbitral Awards' (DPhil thesis, University of Hull 2008).

Al-Talhuni, Hussam, 'The Effect of Public Policy on the Enforcement of Foreign Arbitral Awards' (DPhil thesis, The University of Edinburgh 2002).

Al-Tamimi, Essam, Practitioner's guide to arbitration in the Middle East and North Africa (JurisNet LLC 2009).

Ar-Rahman, Abd and Clarke, Abdassamad, Shari'a Islamic Law (Ta-Ha Publishers 2008).

Ayad, Mary, 'International Commercial Arbitration and Harmonisation of Contract Law with a Focus on Reform in the Mena Region' (2009) 6 MqJBL 93.

Baamir, Abdulrahman, Shari'a Law in Commercial and Banking Arbitration: Law and Practice in Saudi Arabia (Ashgate 2010).

Baamir, Abdulrahman and Bantekas, Ilias, 'Saudi Law as Lex Arbitri: Evaluation of Saudi Arbitration Law and Judicial Practice' (2009) 25 J of Arb Int'l 239.

Ballantyne, William, Arab Comparative and Commercial Law: The International Approach (Graham Trottman 1987) vol 1.

Bird, Robert, 'Enforcement of Annulled Arbitration Awards: A Company Perspective and an Evaluation of a "New" New York Convention' (2011-2012) 37 NCJ Int'1 L \& Com Reg 1013.

Born, Gary, International Commercial Arbitration, (Kluwer 2014) vol I.

Brower, Charles and Sharpe, Jeremy, 'International Arbitration and the Islamic World: The Third Phase' (2003) 97 AJIL 643.

Dawes, J, 'Do Data Characteristics Change According to the Number of Scale Points Used?: An experiment using 5-point, 7-point and 10-point scales' (2008) Int'1 J of Market Research 50, 61-77.

Edge, Ian (ed), Islamic Law and Legal Theory (Dartmouth 1996) xvi-xvii.

El-Ahdab, Abdul Hamid, 'General Introduction on Arbitration in Arab Countries' in Pieter Sanders (ed), International Handbook on Commercial Arbitration (Kluwer 1993). El-Ahdab, Abdul Hamid and El-Ahdab, Jalal, Arbitration with the Arab Countries (3rd edn, Wolters Kluwer 2011). 
Elattar, Amr, Enforcement of International Arbitration Awards: A Comparative Study between Egypt, USA, and the Gulf Cooperation Council Countries (LAP Lambert Academic Publishing 2013).

El-Kadi, Omar, 'L'Arbitage International entre le Droit Musulman et le Droit Francais et Egyptien' (DPhil thesis, University of Paris 1984).

Elsaman, Radwa, 'Factors to Consider Before Arbitrating in the Arab Middle East: Religious and Legislative Constraints' (2011) 3 Geo Mason J Int'1 Com L 1.

Ezrahi, Ariel, 'Arbitration in the Arab Middle East, a Snapshot' (2005) 20-11 Measley's Int'l Arb Rep 17, 5.

Gharavi, Hamid and Karam, Lara, 'Arbitration in Yemen' (2006) 17 ICC International Court of Arbitration Bulletin 41.

Hamid, M. 'Islamic Law of Contract or Contracts', Journal of Islamic and Comparative Law, 3 (1969), 1.

Hwang, Michael and Lee, Shaun, 'Survey of South East Asian Nations on the Application of the New York Convention' (2008) 25(6) J of Intl Arb 873-892.

Kawach, N ., 'Gulf states plan single arbitration law' (22 Aug 2009), Emirates Business 24/7, available at http://www.emirates247.com/eb247/economy/uae-economy/gulf-statesplan-single-arbitration-law-2009-08-22-1.30548 (last accessed 20 Feb 2014);

Kutty, Faisal, 'The Shari'a Factor in International Commercial Arbitration' (2006) 28 Loy LA Int'1 \& Comp L 1, (2009) 4 J of Arab Arb 63.

Levi-Tawil, Elana, 'East Meets West: Introducing Shari'a Into the Rules Governing International Arbitrations at the BCDR-AAA' (2011)12 Cardozo J of Conflict Resolution 609.

Maniruzzaman, AFM, 'International Commercial Arbitration in the Asia Pacific: Asian Values, Culture and Context' (2002) 30 Int'1 Bus Lawyer 11.

Moens, Gabriel and Jones, Roger (eds), International Trade and Business Law Review, vol XII (1st edn, Routledge-Cavendish 2009).

Mohammed, N., 'Principles of Islamic Contract Law', Journal of Law and Religion, 6 (1988), p. 115.

Nussbaum, Arthur, 'Public Policy and the Political Crisis in the Conflict of Laws' (1940) 49 Yale L J 1027. 
Rashid, Syed Khaled, 'Alternative Dispute Resolution in the Context of Islamic Law' (2004) 8 Vindobona J Intl Com L 95.

Reed, Lucy, Paulsson, Jan and Blackaby, Nigel, Guide to ICSID Arbitration (Wolters Kluwer 2010).

Saleh, Samir, Commercial Arbitration in the Arab Middle East (2nd edn, Hart Publishing 2006).

Samir Saleh, 'The Recognition and Enforcement of Foreign Arbitral Awards in the States of the Arab Middle East' (1985) 1 Arab L Q 19, 26.

Sheta, Ahmed, 'GCC Unified Arbitration Draft Law’ (2009)1 J Arab Arb 92.

van den Berg, Albert, The New York Arbitration Convention of 1958: Towards a Uniform Judicial Interpretation (Kluwer 1981).

van den Berg, Albert Jan, 'When is an Arbitral Award Nondomestic Under the New York Convention of 1958?' (1985) 6 Pace L Rev 25.

Wakim, Mark, 'Public Policy Concerns Regarding Enforcement of Foreign International Arbitral Awards in the Middle East' (2008) 21 NY Int'1 L Rev 1.

\section{Cases}

AA Commercial Co v S Motors Ltd Co and D Industrial Ltd Co, Abu-Dhabi Court of Appeal, Case No 10007/1981 unpublished.

Abu Dhabi Court of Cassation, Petition No 814/2011, Judgment of 21 December 2011.

Abu Dhabi Court of Cassation, Appeal No 519 of 2013, Decision on 2 October 2013.

Bahrain Supreme Court, Challenge No 241 of 2008 (17 November 2008).

Baiti Real Estate Development v Dynasty Zarooni Inc, Dubai Court of Cassation, Appeal No 14/2012, Real Estate Cassation (16 September 2012).

Cairo Court of Appeals, Seventh Commercial Circuit, Case No 50/128j (4 January 2012).

Case No 127, Appeal No 10/2000, Supreme Court Decision (Oman).

Dubai Court of Cassation Judgment 267/99 (November 1999). 
Dubai Court of Cassation Judgment 17/2001 (3 October 2001).

Dubai Court of Appeal, Civil Petition No 531/2011, Judgment of 6 October 2011.

Dubai Court of Cassation, Petition No 17/2001, Judgment of 10 March 2011.

Federal Supreme Court, Petition No 32, 23rd Judicial Year, Judgment of 8 June 2003.

Final Award No 7063 (1993), (1997) 22 YB Comm Arb 87, IADR Ref No 112 (Saudi Arabia).

Fujairah Federal Court of First Instance, Commercial Case No 35/2010, Judgment of 27 April 2010.

G Steel Industry Co v International Steel and Contractors Co, UAE Supreme Court Case No 138/10, unpublished.

High Federal Court of Abu Dhabi, Annulment Case No 891, Commercial Cassation, Hearing held 17 June 2006.

Hubco v WAPDA, Civil Appeal Nos 1398 and 1399 of 1999 (Pakistan), (2000) 16 Arbitration Int'1 439.

Kuwait Court of Appeals, Request for Arbitration No 16/2001 (8 May 2006).

Oman Appeal Circuit, Hearing session held on October 19, 1998, Case No 2/98 Arbitration, (2010) J of Arab Arb 198.

Qatari Court of Appeals, Case No 107/1994, Judgment rendered in the hearing of 8 May 1995, (2009) J Arab Arb 438.

Saudi Arabia Court of Grievance, Commercial Circuit, Case No 1767/2/J of 1422 AH, Ruling No 183/C/C/9 of $1425 \mathrm{AH}$.

\section{Statutes}

Convention on the Recognition and Enforcement of Foreign Arbitral Awards, 10 June 1958, art V(2)(b), 21 UST 2517, 330 UNTS 38 [New York Convention]

'Draft of Unified Law for Arbitration in States of Gulf Cooperation Council' (2009) 1 J Arab Arb 559.

International Legal Framework, (1994) 1 World Arb Rep 1, 37. 
Law of Mar 15, 1961, § 2, Bundesgesetzblatt [BGBI] II, 121 (W Ger).

UNCITRAL Model Law on International Commercial Arbitration 1985 with amendments as adopted in 2006.

\section{Online Sources}

Bajaj, Gitanjali. 'Arbitration in the Kingdom of Saudi Arabia' (DLA Piper News 2009) $\square$ http://www.dlapiper.com/arbitration-in-the-kingdom-ofsaudi-arabia/ $\square$ accessed 18 January 2014.

Hoyle, Mark, 'Topic in focus: demystifying UAE arbitration law' (Lexology, 8 November 2013) $\square$ http://www.lexology.com/library/detail.aspx?g=fc4ff6d6-cafb-40638dc1-f20fc1544c9e $\square$ accessed 15 January 2014.

Kandady, Satish, 'Unified GCC Arbitration Law Set to Take Effect Next Year' The Peninsula (Doha, 7 April 2009)

$\square$ http://www.thepeninsulaqatar.com/Display_news.asp?section=business_news\&month =april2009\&file=business_news2009040722050.xml $\square$ accessed 21 February 2014.

Karrar-Lewsley, Robert, 'UAE: attachment orders apply while recognition is pending' (Lexology, 23 January 2014)

$\square$ http://www.lexology.com/library/detail.aspx?g=42bd95b7-730a-4341-b93ad2d064e911fd $\square$ accessed 24 February 2014.

Kawach, Nadim, 'Gulf states plan single arbitration law' (Emirates Business 24/7, 22 August 2009) $\square$ http://www.emirates247.com/eb247/economy/uae-economy/gulf-statesplan-single-arbitration-law-2009-08-22-1.30548 $\square$ accessed 20 February 2014.

\section{Shari'a Sources}

Abu Hanifa, Badaei El Sanaei, 132 and et seq.

Abu Yussef, Badaei El Sanaei, 132 and et seq.

Al Charh Al Kabir, vol IV 383.

Imam Malik, Mawaheb Al Jalil, vol III, 355.

Imam Shafi'i, AL Muhazab, vol II, 358.

Imam Ibn Hanbal, Al Mughni, vol X 439. 